The Disintegration of the Wolf Creek Meteorite and the Formation of Pecoraite,

the Nickel Analog of Clinochrysotile

GEOLOGICAL SURVEY PROFESSIONAL PAPER 384-C

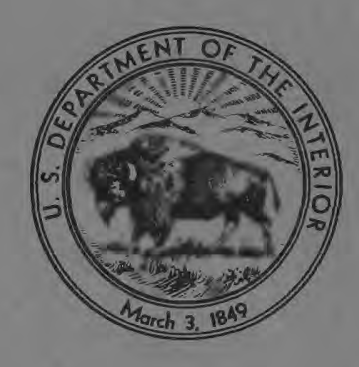



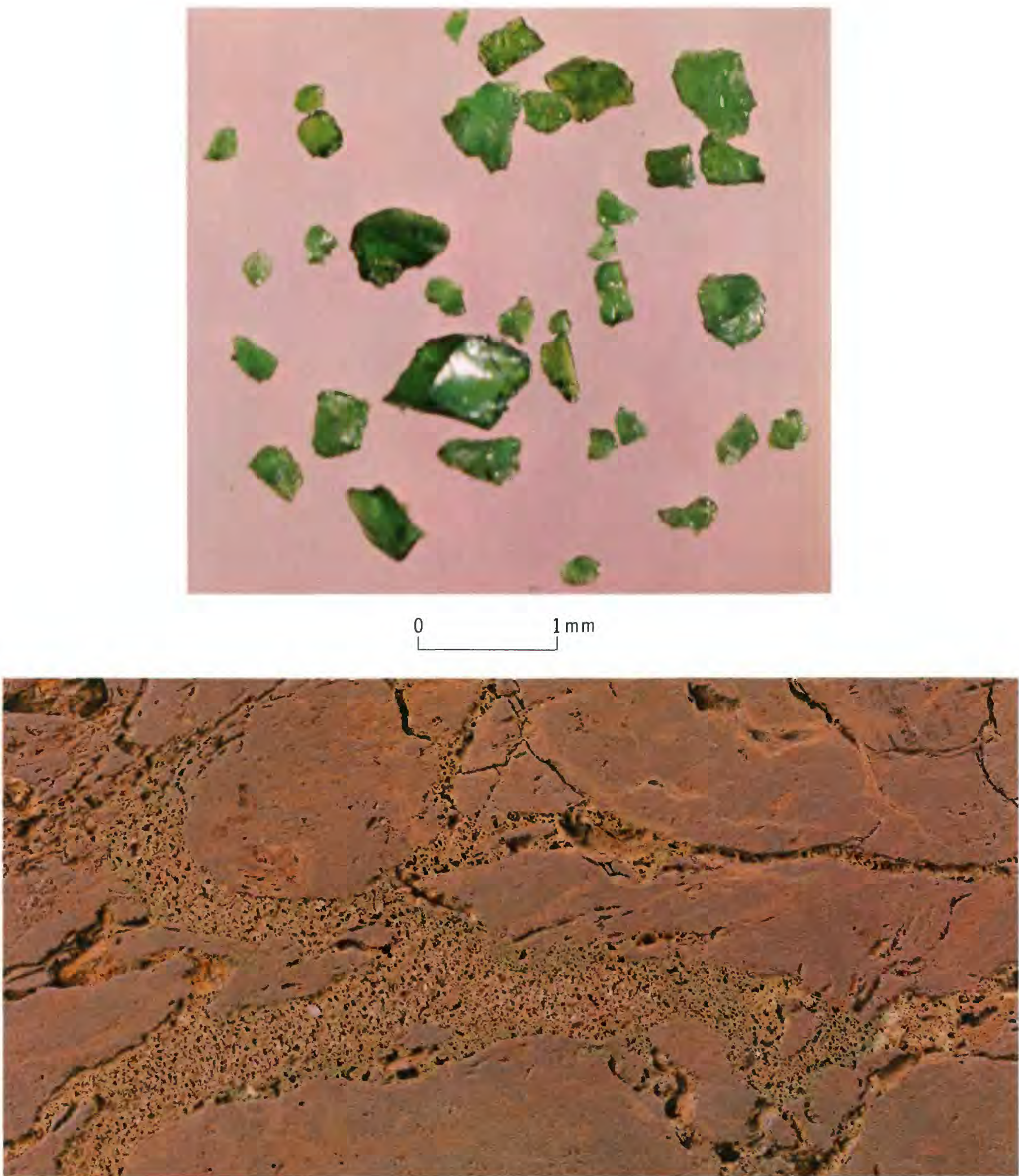

0 $1 \mathrm{~cm}$

Pecoraite, Wolf Creek meteorite of Australia. Upper, Pecoraite grains separated by hand picking from crack fillings in the meteorite (X 25). Lower, Pecoraite grains lining the walls of some cracks in the meteorite. The extent of disintegration of the original metallic phases into new phases, chiefly goethite and maghemite, is apparent (X 2.3). 
THE DISINTEGRATION OF THE WOLF CREEK METEORITE AND THE FORMATION OF PECORAITE, THE NICKEL ANALOG OF CLINOCHRYSOTILE 


\section{The Disintegration of the Wolf Creek Meteorite and the Formation of Pecoraite, the Nickel Analog of Clinochrysotile}

BY GEORGE T. FAUST, JOSEPH J. FAHEY, BRIAN H. MASON and EDWARD J. DWORNIK

STUDIES OF THE NATURAL PHASES IN THE SYSTEM MgO- $\mathrm{SiO}_{2}-\mathrm{H}_{2} \mathrm{O}$ AND THE SYSTEMS CONTAINING THE CONGENERS OF MAGNESIUM

GEOLOGICAL SURVEY PROFESSIONAL PAPER $384-\mathrm{C}$

Origin of pecoraite elucidated through its properties and in terms of the geochemical balance in its desert environment

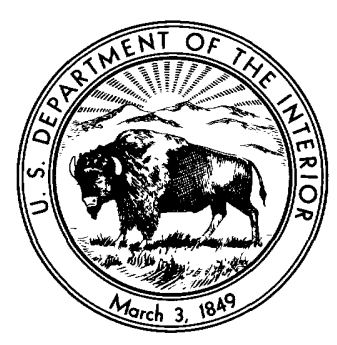

UNITED STATES GOVERNMENT PRINTING OFFICE, WASHINGTON : 1973 
UNITED STATES DEPARTMENT OF THE INTERIOR

ROGERS C. B. MORTON, Secretary

\section{GEOLOGICAL SURVEY}

V. E. McKelvey, Director

Library of Congress catalog-card No. 73-600160

For sale by the Superintendent of Documents, U.S. Government Printing Office

Washington, D.C. 20402 - Price $\$ 1.30$

Stock Number 2401-02392 


\section{CONTENTS}

Abstract

Introduction -

Acknowledgments

Pecoraite -

Preparation of sample

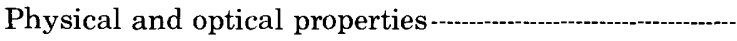

Crystallographic studies

Electron-microscopic examination -.........................

X-ray powder diffraction studies-

Geometrical relations of the curved sheets of pecoraite to the cylindrical structure of clinochrysotile

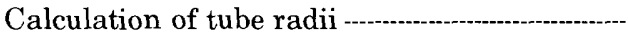

Interpretation of diffraction effects---.--.---.-

Interpretation of tube morphology

Chemical properties

Pyrognostics

Chemical analysis and composition-...-...-...-...-

Microprobe analysis -

Studies on pecoraite and related synthetic phases in the system $\mathrm{H}_{2} \mathrm{O}-\mathrm{NiO}-\mathrm{SiO}_{2}$

\begin{tabular}{|c|c|}
\hline & \\
\hline 107 & Thermal-analysis studies \\
\hline 107 & Static (dehydration) method -. \\
\hline 107 & Dynamic (differential-thermal-analysis) method -------- \\
\hline 107 & Disintegration of the Wolf Creek meteorite and the forma- \\
\hline 107 & tion of pecoraite-1-1-n \\
\hline 108 & Time, temperature, and pressure relations of the nat- \\
\hline 108 & \\
\hline 108 & Behavior of a model meteorite body in a d \\
\hline 108 & s---- \\
\hline & Stre \\
\hline & Natural \\
\hline 112 & Com \\
\hline 112 & Stress relations resulting fr \\
\hline 112 & Physical and chemical characteristics and rela- \\
\hline & \\
\hline 11 & ------- \\
\hline 11 & - \\
\hline & \\
\hline & cite \\
\hline
\end{tabular}

118
Page

119

119

119

\section{ILLUSTRATIONS}

FrontisPIFCE. Pecoraite from the Wolf Creek meteorite of Australia.

FiguRES 47, 48. Electron micrograph of pecoraite, showing morphology

49, 50. Electron micrographs of the synthetic clinochrysotile of Bowen and Tuttle (1949)-

51. Thermal-analysis curve of pecoraite obtained by the static method -a- 119

52. Differential-thermal-analysis curves of a partly purified sample of pecoraite from the Wolf Creek meteorite of Australia -

53. Graph showing daily and nightly temperature extremes of the air above the soil and of the soil in the desert floor

54. Photograph showing crack development in the Wolf Creek meteorite-

\section{TABLES}

TABLE 1. X-ray powder diffraction data for pecoraite obtained from powder photographs

2. Calculated values of the thickness of the curved plates of pecoraite, based on measurements derived from powder patterns-

3. Calculated values of the thickness of the curved plates of pecoraite, based on half width measurements of line breadth derived from X-ray powder diffractometer patterns --oup

4. X-ray powder diffraction data for synthetic nickel serpentine group minerals ----owen and Tuttle (1949) and for
5. Half-width measurements of line breadths for clinochrysotile synthesized by Bowen clinochrysotile from the Currant Creek magnesite deposit, White Pine County, Nev.-

6. Fiber dimensions and wall thickness of chrysotile, synthetic chrysotile, and synthetic pecoraite derived from $\mathrm{X}$-ray studies and electron microscopy

7. Chemical analysis of pecoraite from the Wolf Creek meteorite, Wolf Creek, Australia- 
TABLE 8. Chemical analysis of some synthetic products related to or containing pecoraite

9. Thermal-analysis data obtained by the static method on pecoraite from the Wolf Creek meteorite, Western Australia-

10. Calculated temperature and thermal stress in model meteorite bodies in the shape of a sphere, a cylinder, and a slab-

11. Distribution of the elements in the disintegration products of the Wolf Creek meteorite and in the source materials-a study of geochemical balance-- 


\title{
THE DISINTEGRATION OF THE WOLF CREEK METEORITE AND THE FORMATION OF PECORAITE, THE NICKEL ANALOG OF CLINOCHRYSOTILE
}

\author{
By George T. Faust, Joseph J. Fahey, Brian H. Mason, ${ }^{1}$ and Edward J. Dwornik
}

\section{ABSTRACI}

The Wolf Creek meteorite fell in Western Australia (lat $19^{\circ} 11^{\prime} \mathrm{S}$., long $127^{\circ} 48^{\prime}$ E.) during Pliocene or, at the latest, Pliocene-Pleistocene time and produced an impact crater. Original metallic compounds in the meteor became mechanically unstable in the desert environment because of the constant alternation in thermal conditions over a long period of time. The meteorite was heated by the sun to over $100^{\circ} \mathrm{C}\left(212^{\circ} \mathrm{F}\right)$ in the daytime, and its temperature dropped to about $15^{\circ} \mathrm{C}\left(59.0^{\circ} \mathrm{F}\right)$ at night. This cycle ultimately reduced the mechanical strength of parts of the meteorite and caused it to rupture and form thin cracks. During the rainy season, moisture entered the cracks, and stress corrosion became operative, which further reduced the mechanical strength of the meteonite and brought about chemical corrosion. The moisture also widened the cracks. Sand particles blown by the wind entered the cracks, where they were crushed during the cooling cycle. Repeated dropping and crushing of the sand further widened the cracks. During the heating cycle, these cracks, which contained finely crushed silica, nickel ions in solution, and other inactive solid phases, behaved like tiny hydrothermal bombs and introduced: their load of nickel ions, by overflow, into the hydrothermal solutions in larger cracks, where pecoraite, $\mathrm{Ni}_{6} \mathrm{Si}_{4} \mathrm{O}_{10}(\mathrm{OH})_{8}$, was formed in very small amounts over long periods of time.

The phase pecoraite was described by Faust, Fahey, Mason, and Dwornik in 1969, and a detailed description of it is presented here to document the species and to provide background for the investigation of the process of disintegration of the meteorite.

\section{INTRODUCTION}

White, Henderson, and Mason (1967) studied the secondary minerals produced in the disintegration of the Wolf Creek meteorite in the Wolf Creek crater in Western Australia (lat $19^{\circ} 11^{\prime}$ S., long $127^{\circ} 48^{\prime}$ E.) and found a green nickel mineral, tentatively identified as belonging to the serpentine group, occurring as a filling in cracks transecting the meteorite. This green phase, the nickel analog of clinochrysotile, was briefly described by Faust, Fahey, Mason, and Dwornik (1969) and was named "pecoraite"2 (PE KAWR'E AIT).

${ }^{1}$ U.S. National Museum of Natural History, Smithsonian Institution, Washington, D.C. 20560 .
It is the purpose of this paper first to document, in detail, the mineral pecoraite and to add some further data on the Wolf Creek meteorite; secondly, to contribute to the knowledge of the natural phases in the system $\mathrm{H}_{2} \mathrm{O}-\mathrm{MgO}-\mathrm{NiO}-\mathrm{SiO}_{2}$; and thirdly, to present a coherent theory for the probable course of the disintegration of the Wolf Creek meteorite in its crater and for the development of the phase assemblage now observed.

\section{ACKNOWLEDGMENTS}

We thank David B. Stewart, J. Stephen Huebner, and Mary E. Woodruff, all of the U.S. Geological Survey, for preparing the diffractometer traces, and we thank John W. White, of the U.S. National Museum, for an X-ray pattern and other aid. Michael Fleischer translated parts of Russian scientific papers and offered advice.

Discussions with our colleagues Paul B. Barton, Jr., John L. Haas, Malcolm Ross, and Motoaki Sato are greatly appreciated.

\section{PECORAITE \\ PREPARATION OF SAMPLE}

The mineral pecoraite occurs in an aggregate of medium- to fine-grained particles in cracks in the Wolf Creek meteorite. Pecoraite is present in this aggregate as grains approximately $0.1-0.5 \mathrm{~mm}$ (millimeter) in diameter. All the phases in the aggregate are intergrown or are coated by associated phases so that preliminary separations were very difficult. Extensive handpicking was required to prepare a pure sample.

The material in the cracks is composed chiefly of intergrown maghemite and goethite with minor quantities of adventitious quartz sand and clay-size material and a very small amount of the green nickel

${ }^{2}$ Approved by the International Mineralogical Association Commission on New Minerals and Mineral Names. 
silicate, pecoraite, About $200 \mathrm{~g}$ (grams) of this material was scraped from the cracks and crushed to pass through a 20-mesh sieve. The amount of pecoraite in this sample was visually estimated to be 1 percent.

Most of the maghemite and intergrown goethite was removed by means of an Alnico magnet. These minerals made up more than 95 percent of the material taken from the cracks in the meteorite. The residue at this point consisted of about 25 percent pecoraite and an assemblage of adventitious quartz sand, clay-size material, goethite, cassidyite, reevesite, and a very small amount of silicon carbide introduced during slicing of the meteorite. The Franz Isodynamic Separator did very little to purify the sample further, but a heavy liquid (bromoform and acetone) was used which increased to about 50 percent the amount of pecoraite present.

The sample was then repeatedly treated with acetone and, after decantation, allowed to remain for about 10 days at room temperature in an uncovered beaker. From this material a sample that weighed $160 \mathrm{mg}$ (milligrams) and was better than 99.9 percent pure pecoraite was obtained by handpicking under a binocular microscope.

\section{PHYSICAL AND OPTICAL PROPERTIES}

Pecoraite has a hardness of $2 \frac{1}{2}$. The compact masses of pecoraite are brittle and have a conchoidal fracture. The color of pecoraite is "Oriental Green" as defined and illustrated on Plate XVIII of "Color Standards and Color Nomenclature," by Robert Ridgway (1912). Its luster is vitreous to waxy. Photographs of the grains and their occurrence in cracks are shown in the frontispiece.

The specific gravity of 3.084 , as determined by the method of Fahey (1961), is in poor agreement with the calculated value 3.514 based on Brindley's (1961) values for the unit cell of "Ni serpentine." Our low value may be due to the large amount (4.1 percent) of adsorbed water and too many tiny liquid and gas inclusions. Our value is in better agreement with the value of 3.18 determined by the pycnometric method on synthetic percoraite by Noll, Kircher, and Sybertz (1958).

The mean index of refraction, $n$, measured on many grains ranged from 1.565 to 1.603 . This range is probably due to variations in the adsorbed water and, in a very much lesser part, to variations in $\mathrm{NiO}, \mathrm{FeO}$, and $\mathrm{MgO}$ among the grains. Grains of pecoraite are weakly doubly refracting. On some grains, wavy extinctions were observed under crossed polarizers. Other grains showed no extinction when the stage of the microscope was rotated, indicating an anomalous condition probably related to the orientation of the submicroscopic particles that constitute the grains and which render them isotropic through optical compensation. To determine the effect of the adsorbed water on the index of refraction of the grains, two experiments were made. In the first, the grains of pecoraite were placed in a porcelain dish and set in an oven at $148^{\circ} \mathrm{C}$ for 16 days. They were then removed from the oven and allowed to cool in a dessicator. These dried grains were placed in quinoline $(n=1.6245)$ and allowed to soak for a day or more. Most grains then had a mean index of refraction greater than 1.625. In the second experiment, pecoraite was dried over the dessicant, anhydrous magnesium perchlorate, for 32 days and then examined in an immersion liquid having an index of refraction of 1.650. Most grains then nearly matched the index of refraction of the liquid. This mean value of $n=1.650 \pm$ is in good agreement with the value of $n=1.654$ measured by Noll, Kircher, and Sybertz (1960) for synthetic pecoraite. It also agrees well with the value of $n=1.655$ calculated with the GladstoneDale relation using a specific gravity of 3.18 as measured on synthetic pecoraite by Noll, Kircher, and Sybertz (1958).

\section{CRYST ALLOGRAPHIC STUDIES}

/ELECTRON-MICROSCOPIC EXAMINATION

Part of the carefully purified sample prepared for the chemical analysis was examined under the electron microscope. The electron micrographs (figs. 47,48 ) disclose the morphology of pecoraite to be curved plates which are in various degrees of curling. Some are curved to form incomplete coils, whereas others have curved to form one or more complete turns and have thus generated spirals. When the spirals stand on end, as in the aggregates or clusters', they appear to be circular. The diameter of the spirals is approximately $250 \mathrm{~A}$, and the width of the individual coil is approximately $70 \mathrm{~A}$.

A search of several fields under the electron microscope did not disclose any spirals with enough complete revolutions to form long coils such as those observed for lipids by Glauert and Lucy (1969a,b). The spirals shown in figures 47 and 48 formed only three, four, or five complete revolutions about the spiral axis.

\section{X-RAY POWDER DIFFR.AC.IFN STIDIES}

X-ray powder diffraction patterns were made of pecoraite using both the camera and film and the diffractometer techniques. More reflections were recorded on the films than on the diffractometer patterns. The diffractometer patterns, however, gave information on the character of the peaks that was 


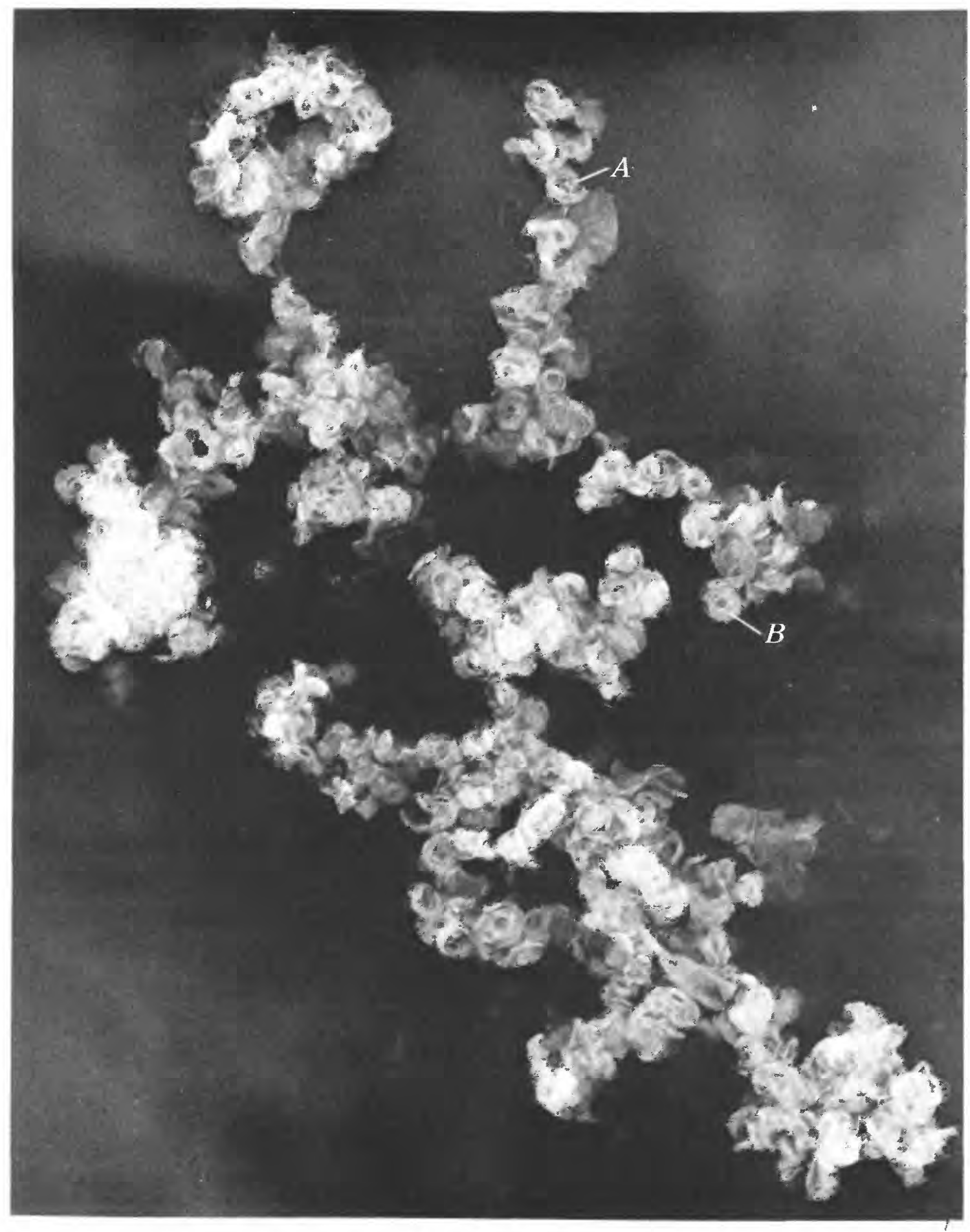

FIGURE 47.-Electron micrograph of pecoraite, showing morphology of curved plates in various degrees of coiling; $A$, incomplete coils; $B$, spirals standing on end (supported in cluster groups). About X 180,000.

not discernible from the lines recorded on the films. The films yielded a sufficient number of reflections to identify the phase.

Specimens of the ground pecoraite were tamped into specially drawn capillary tubes of $0.2 \mathrm{~mm}$ diameter. X-ray powder photographs and diffracto- meter traces were obtained for both the natural dry sample and the ethylene glycol permeated pecoraite. The X-ray powder diffraction pattern of pecoraite consists of a series of rather broad lines, probably resulting from the fine grain size of the material (Scherrer, 1918). The broadening of the lines in- 


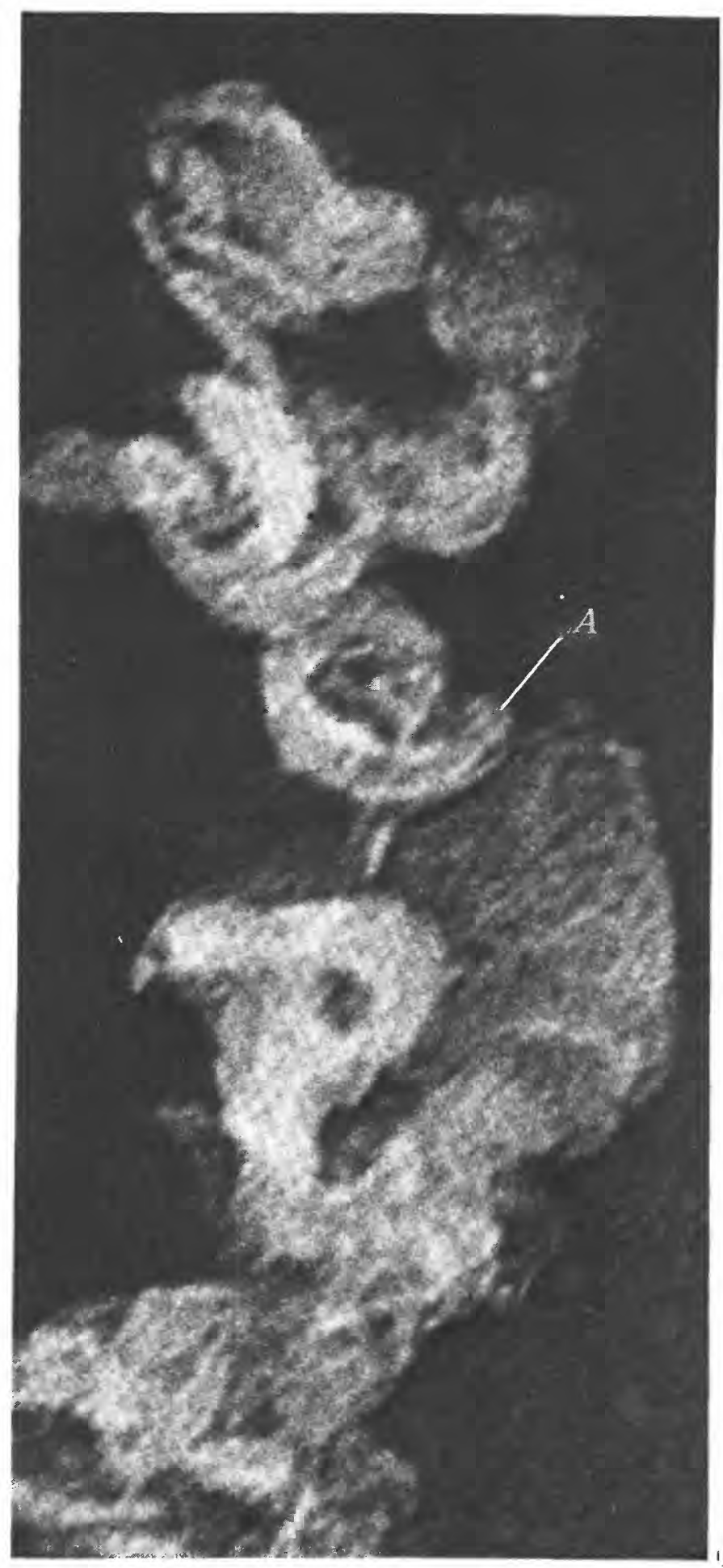

FIGURE 48.-Electron micrograph of pecoraite, showing, in detail, the incompletely curved plates (A). About X 960,000.

troduces uncertainty into the measurement of the position of the lines and, consequently, of the $d$ spacings.

Ross (1968) has also shown that for thin plates, generally, the first-order $00 l$ reflection shifts to smaller values of $2 \theta$ and the apparent $d_{001}$ increases. Higher order reflections may shift to either smaller or larger values of $2 \theta$ depending on the nature of the Fourier transform of the single layer. Line broadening also results from order-disorder phenomena.

Three X-ray powder diffraction patterns of pecoraite were measured, and the results are given in table 1. From these data of the line-breadth, calculations were made to determine particle size by means of the von Laue (1926) and Scherrer (1918) relation as modified by Wilson (1949) and Stokes and Wilson $(1942,1944)$.

The von Laue and Scherrer relation is

where

$$
\beta 1 / 2=\frac{K \lambda}{t \cos \theta}
$$

$\beta_{1 / 2}=$ measured line breadth at half intensity (given in radians $2 \theta$ ) (on powder photographs the eye estimates a value equal to approximately one-half width because of its inability to discriminate between background and line boundaries);

$\lambda$ = wavelength of radiation, in angstroms;

$t=a$ linear dimension of the particle, in angstroms;

$\boldsymbol{\theta}=$ Bragg angle; and

$K=$ the Scherrer constant, commonly about 0.90 but varying a few percent with particle shape.

Electron-microscope study of part of the sample of pecoraite used in the chemical analysis suggested that some of the particles were curved plates. Using the von Laue and Scherrer relation, the thickness of the plates of pecoraite was calculated from the X-ray powder diffraction patterns (table 2). The average thickness of the curved plates of pecoraite calculated from these data is $74.1 \mathrm{~A}$. Assuming, for comparison, the thickness of a single layer ${ }^{3}$ of clinochrysotile to be 7.3 $\mathrm{A}$ and dividing this into $74.1 \mathrm{~A}$ gives 10.1 as the probable number of layers in the pecoraite plates.

Similar data were obtained from diffractometer traces of pecoraite taken with copper radiation and using a nickel filter. These patterns exhibited a small number of broad rounded peaks having subdued peak heights. Such diffraction effects arise from the fine particle size, which causes a broadening of the reflections.

Using the von Laue (1926) and Scherrer (1918) relation, as before, the data for the particle thickness, $t$, of pecoraite curved plates as determined from the half-width line-breadth measurements of the dif-

${ }^{3}$ Whittaker (1957), for computation, used the halved value of $c(7.3 \mathrm{~A})$ for a single layer. 
TABLE 1.-X-ray powder diffraction data for pecoraite obtained from powder photographs

[Copper radiation and nickel filter, $\lambda=1.54050 \mathrm{~A}$; films uncorrected for shrinkage; camera diameter, $114.59 \mathrm{~mm}$. The intensity, 1, based on the $\sqrt{2}$ scale, was visually estimated and converted to a linear scale. The line breadth is the average of 6 measurements and is given as the difference $2 \theta^{\prime \prime}-2 \theta^{\prime}$ at approximately ${ }^{1 / 2}$ width. $\mathrm{Db}$, diffuse band; $\mathrm{P}$, present, but too diffuse to measure; $\mathrm{D}$, diffuse $\mathrm{B}$, broad]

\begin{tabular}{|c|c|c|c|c|c|c|c|c|c|}
\hline \multirow{2}{*}{$h k l^{1}$} & \multicolumn{3}{|c|}{$\begin{array}{l}\text { Film } 11006^{:} \\
\text {U.S. Geological Survey }\end{array}$} & \multicolumn{3}{|c|}{$\begin{array}{c}\text { Film } 3671 \\
\text { U.S. National Museum }\end{array}$} & \multicolumn{3}{|c|}{$\begin{array}{c}\text { Film 10972 } \\
\text { U.S. Geological Survey }\end{array}$} \\
\hline & $\begin{array}{c}d_{\text {obs }} \\
\text { (angstroms) }\end{array}$ & I & $\begin{array}{c}\text { Line } \\
\text { breadth } \\
\text { (radians) }\end{array}$ & $\begin{array}{l}d_{\text {obs }} \\
\text { (angstroms) }\end{array}$ & I & $\begin{array}{c}\text { Line } \\
\text { breadth } \\
\text { (radians) }\end{array}$ & $\begin{array}{c}d_{\text {obs }} \\
\text { (angstroms) }\end{array}$ & I & $\begin{array}{c}\text { Line } \\
\text { breadth } \\
\text { (radians) }\end{array}$ \\
\hline 002 & 7.43 & 100 & 0.01919 & 7.43 & 100 & 0.01919 & 7.43 & 100 & 0.02094 \\
\hline 020 & 4.50 & 35 & .02094 & 4.49 & 17 & .02094 & 4.49 & 35 & .01745 \\
\hline 004 & 3.66 & 50 & .02269 & 3.63 & 36 & .02094 & 3.65 & 50 & .02443 \\
\hline 130 & 2.620 & 35 & .02792 & 2.63 & 25 & .01745 & 2.627 & 50 & .01745 \\
\hline $20 \overline{2}$ & -... & $\mathrm{Db}$ & --.-- & ..... & $\mathrm{Db}$ & - & 2.554 & $\mathrm{Db}$ & 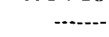 \\
\hline 202 & 2.447 & 25 & .02443 & 2.447 & 17 & .01745 & 2.443 & 35 & .02094 \\
\hline 204 & $\mathrm{P}$ & $\mathrm{D}$ & B & 2.106 & 13 & B & 2.116 & 13 & B \\
\hline 060 & 1.529 & 50 & .02269 & 1.524 & 25 & .01745 & 1.527 & 50 & .02269 \\
\hline $40 \overline{2}$ & 1.303 & $\mathrm{Db}$ & B & 1.300 & $\mathrm{Db}$ & B & 1.305 & $\mathrm{Db}$ & B \\
\hline
\end{tabular}

The indexing is probable and is based on analogy to the indexing of Whittaker and Zussman (1956).

2Obtained with a special low-angle slit assembly.

"The accidental recording of a "brass line" on film 10972 produced a sharp, narrow line in contrast to the lines of pecoraite and served both to emphasize the difference in the diffracting characteristics of the two substances and as a check on the calibration.

fractometer traces are given in table 3. For peaks with asymmetrical bases the geometric method of Halla and Mark (1937, fig. 158, p. 318) was used to obtain $\mathrm{I} / 2$. The average value of $t$ from the two calibrated measurements is $71 \mathrm{~A}$ which, when divided by $7.3 \mathrm{~A}$ (the thickness of a single layer), yields 9.8 multiples of the "clinochrysotile layers." This is in good agreement with the data from the Xray powder diffraction pattern in table 2 . In these calculations no consideration was given to the broadening of the lines owing to order-disorder phenomena which are believed to be of lesser importance.

TABLE 2.-Calculated values of the thickness of the curved plates of pecoraite, based on measurements derived from powder patterns

[Copper radiation and nickel filter; $\lambda=1.54050 \mathrm{~A}]$

\begin{tabular}{|c|c|c|c|c|c|c|}
\hline Film & $h k l$ & $\begin{array}{c}\text { Line } \\
\text { breadth } \\
\text { (radians) }\end{array}$ & $\begin{array}{l}2 \theta \text { uncorrected } \\
\text { (degrees) }\end{array}$ & 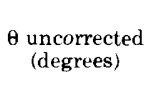 & $\operatorname{Cos} \theta$ & $\begin{array}{l}\text { Thickness } \\
\text { of curved } \\
\text { plates } \\
\text { (angstroms) }\end{array}$ \\
\hline 11006 & 002 & 0.01919 & 11.90 & 5.95 & 0.99461 & 80.7 \\
\hline 11006 & 004 & .02269 & 24.30 & 12.15 & .97759 & 69.5 \\
\hline 3671 & 002 & .01919 & 11.90 & 5.95 & .99461 & 80.7 \\
\hline 3671 & 004 & .02094 & 24.50 & 12.25 & .97723 & 75.3 \\
\hline 10972 & 002 & .02094 & 11.90 & 5.95 & .99461 & 74.0 \\
\hline 10972 & 004 & .02443 & 24.35 & 12.17 & .97750 & 64.5 \\
\hline
\end{tabular}

The data in table 1 show that $d_{002}$ for pecoraite is $7.43 \mathrm{~A}$, and in table 3 the values range up to $7.46 \mathrm{~A}$. These values are much larger than $d_{002}$ for clinochrysotile, which is 7.36 A. The substitution of nickel for magnesium would not be expected to cause this difference, for the difference between the ionic radii of nickel $(0.69 \mathrm{~A})$ and magnesium $(0.66 \mathrm{~A})$ is not large. The explanation must be related to the small size and thickness of the spirals of pecoraite. Malcolm Ross (written commun., 1969) calculated the shift in position of the 002 reflection $\left(d_{002}=7.16 \mathrm{~A}\right)$ of dickite for platelets of various thickness, and he found that for a particle 10 platelets thick, the shift to a larger spacing amounts to $0.1 \mathrm{~A}$; for a particle five platelets thick, the shift is an increase of $0.4 \mathrm{~A}$. The wall thickness of pecoraite is approximately $73 \mathrm{~A}$, or about 10 layers, so the shift from 7.36 A to 7.43-7.46 $\mathrm{A}$ is consistent with Ross' calculation.

\begin{tabular}{|c|c|c|c|c|c|c|}
\hline \multicolumn{7}{|c|}{$\begin{array}{l}\text { TABLF 3.-Calculated values of the thickness of the } \\
\text { of pecoraite, based on half-width measurements } \\
\text { derived from X-ray powder diffractometer patterns } \\
\text { [Copper radiation and nickel filter; } \lambda=1.54050 \mathrm{~A}]\end{array}$} \\
\hline Record & $h k l$ & $d_{\text {obs }} \mathrm{A}$ & $\begin{array}{l}2 \theta^{\prime \prime} \text { uncorrected } \\
\text { (degrees) }\end{array}$ & $\begin{array}{c}2 \theta^{\prime} \text { uncorrected } \\
\text { (degrees) }\end{array}$ & $\begin{array}{c}\beta_{1 / 2}=2 \theta^{\prime \prime}-2 \theta^{\prime} \\
\text { (radians) }\end{array}$ & $\begin{array}{l}\text { Thickness of } \\
\text { curved plates } \\
\text { (angstroms) }\end{array}$ \\
\hline WC-2-1 & 002 & 17.46 & 12.22 & 11.02 & 0.02094 & 74 \\
\hline WC-2-2 & 002 & 17.43 & 12.40 & 11,08 & .02304 & 67 \\
\hline WC $-2-3$ & 002 & $\left({ }^{2}\right)$ & 12.39 & 10.98 & .02461 & 63 \\
\hline WC- $-2-4$ & 002 & $(2)$ & 12.18 & 10.90 & .02234 & 69 \\
\hline
\end{tabular}

${ }^{1}$ Calibrated with quartz

Calibrated with quartz.
¿Uncalibrated, poor pattern with broad peaks.

After examining the data obtained in this study, Malcolm Ross (written commun., 1969) submitted the following two observations:

1. Using the data for $d_{002}$ of record WC-2-1 in table 3 and the relationship of Ross (1968),

$$
W_{1^{\prime} / 2}=2\left(\sin \theta^{\prime}-\sin \theta^{\prime \prime}\right)=\frac{0.90 \lambda}{t},
$$

and setting $\quad W_{1 / 2} \cong \beta_{1,2}$,

I calculated a thickness of $67 \mathrm{~A}$. This calculation serves as an independent check on the results given in this paper.

2 . It is of interest to note that the shift of the $d_{004}$ spacing for 8- to 10-layer models predicted on the basis of Ross'(1968) calculation for dickite is $+0.004 \mathrm{~A}$; thus, the $d_{004}$ value of pecoraite will give the essentially true spacing if the dickite model is valid for the pecoraite structure, as I think it is. The doubled values of the $d_{004}$ 
spacing from table 1 are $7.32,7.26$, and 7.30, suggesting a true $d_{002}$ of $7.29 \mathrm{~A}$. The average $d_{002}$ is $7.43 \mathrm{~A}-$ a difference of $0.14 \mathrm{~A}$. Such a shift suggests an eight-layer model. The average data in table 3 suggest a nine-layer model. The agreement may be fortuitous, but there is agreement between two completely unrelated calculations

The X-ray diffraction powder data (table 4) for synthetic nickel chrysotile and cobalt chrysotile were measured by Feitknecht and Berger (1942) and recalculated by Brindley (1961). Roy and Roy (1954) also prepared synthetic nickel serpentine and recorded the X-ray powder diffraction data (table 4). These data are similar to those for natural pecoraite (table 1) but represent better crystallized phases. Longuet (1947) gave X-ray powder data for a nickel serpentine which she called nickel antigorite, and these data are in table 4.

To be certain that there was no admixture with a phase having a spacing larger than $7.5 \mathrm{~A}$, runs were made, using both powder cameras and the diffractometer, with samples treated with ethylene glycol. Observations were also made with a camera having special slits designed to record low-angle spacings. The results of all these tests failed to disclose any additional phases.

\begin{tabular}{|c|c|c|c|c|c|}
\hline \multicolumn{3}{|c|}{ Feitknecht and Berger (1942) } & \multicolumn{2}{|c|}{ Roy and Roy (1954) } & \multirow{2}{*}{$\frac{\text { Longuet (1947) }}{d \text { (angstroms) }}$} \\
\hline$h k l^{1}$ & $d^{1}$ (angstroms) & I & $d^{1}$ (angstroms) & I & \\
\hline 001 & 7.28 & 10 & 7.26 & 10 & 7.35 \\
\hline 020 & 4.62 & 2 & $\cdots$ & - & 4.52 \\
\hline $0 \overline{002}$ & $3 . \overline{65}$ & $\ddot{10}$ & $\begin{array}{l}4.2 \\
3.629\end{array}$ & $\begin{array}{l}1,2 \\
8\end{array}$ & 3.58 \\
\hline 200 & 2.69 & 6 & -... & .. & 2.65 \\
\hline 201 & 2.506 & 10 & 2.50 & 7 & 2.51 \\
\hline 202 & 2.163 & 6 & 2.14 & 4 & 2.16 \\
\hline 203 & 1.778 & 1 & -- & -- & 1.72 \\
\hline 060 & 1.542 & 10 & 1.52 & $-\overline{4}$ & 1.52 \\
\hline 061 & 1.500 & 2 & $\cdots$ & -. & $\cdots$ \\
\hline 260,063 & 1.310 & 6 & $\cdots$ & -- & 1.30 \\
\hline
\end{tabular}

'Data recalculated by Brindley (1961) on the basis of orthogonal cells.

GEOMETRICAL RELATIONS OF THE CURVED SHEETS OF PECORAITE TO THE CYLINDRICAL STRUICTURE OF CLINOCHRYSOTILE

To interpret the geometrical relations of the curved plates, coils, and spirals of pecoraite to the cylindrical structure of clinochrysotile, it was necessary to consider the structural makeup of the tubes of clinochrysotile and of the synthetic pecoraite. This was done by (a) calculating the tube radii (and diameters) of two clinochrysotiles which gave X-ray powder diffraction patterns almost identical with the pattern of pecoraite, (b) interpreting the diffraction effects of pecoraite and clinochrysotile, and (c) gathering the data in the literature on tube morphology and interpreting all these data in terms of the theoretical model of Whittaker (1957).
CALCULATION OF TUBE RADII

The clinochrysotile (sample F-41) from Currant Creek, Nev., and the synthetic clinochrysotile (sample F-54), No. T-2-29C of Bowen and Tuttle (1949), gave X-ray powder diffraction patterns which resemble most closely the pattern of pecoraite. They both show tubular structure in the electron micrographs (Edward J. Dwornik and George T. Faust, unpub. studies; Bowen and Tuttle, 1949).

The tube radii (and diameters) of these clinochrysotiles were calculated using the modification of the von Laue and Scherrer relation by Wilson (1949) in which the quantity $\epsilon$ is defined as the apparent particle size. For long thin cylinders the equation for equals $(16 / 3 \pi) r \csc \phi$, in which $r$ is the radius of the cylinder, $\phi$ is the angle between the normal to the reflecting planes and the axis of the cylinder, and $b$ is the measured breadth. Thus the complete relation becomes:

$$
b=\frac{\lambda}{\frac{16}{3 \pi} r \csc \phi \cos \theta}
$$

To evaluate the term cosecant $\phi$, the stacking arrangement of the unit cells of clinochrysotile around the cylinder must be known. This arrangement was determined by Whittaker (1956) and summarized by Brindley (1961, p. 90) as follows, using the convention that the $a$ parameter $(a=5.34 \mathrm{~A})$ corresponds to the fiber axis and that the unit cell contains two layers: "With these parameters, $a$ is parallel to the fiber length, and if its structure is tabular, then the $b$ axis follows the circumference of the tube, and $c$ is radial but inclined to the tube axis at the angle $\beta$." For clinochrysotile, $\beta=93^{\circ} 16^{\prime}$.

X-ray data for only the $00 l$ reflexions were examined; for these, $\phi=90^{\circ}$ and $\csc \phi=1$, so the above equation reduces to

$$
b=\frac{\lambda}{\frac{16}{3 \pi} r \cos \theta}
$$

Using data obtained from the diffractometer traces of samples F-41 and F-54, described above, which were made with copper radiation and a nickel filter $(\lambda=1.54050 \mathrm{~A})$, the tube radii (and diameters) were computed. The results are given in table 5 .

INTERPRETATION OF DIFFRACTION EFFECTS

Pecorate and the tubular clinochrysotiles F-41 and F-54 have similar X-ray powder diffraction patterns, and they also show a similar large broadening of the line-breadth profiles on diffractometer traces. The dimensions of the coils and spirals of pecoraite have been described in the previous section on electron 
TABLE 5.-Half-width measurements of line breadths for clinochrysotile synthesized by Bowen and Tuttle (1949) and for clinochrysotile from the Currant Creek magnesite deposit, White Pine County, Nev.

[Diffractometer traces made with copper radiation using a nickel filter, $\lambda=1.54050 \mathrm{~A}$ ]

\begin{tabular}{|c|c|c|c|c|c|c|}
\hline Sample & $h k l$ & $\begin{array}{c}2 \theta^{\prime \prime} \\
\text { uncorrected } \\
\text { (degrees) }\end{array}$ & $\begin{array}{c}2 \theta^{\prime} \\
\text { uncorrected } \\
\text { (degrees) }\end{array}$ & $\begin{array}{c}\boldsymbol{\beta}_{1 / 2} \approx\left(2 \theta^{\prime \prime}-2 \theta^{\prime}\right) \\
\text { (radians) }\end{array}$ & $\begin{array}{c}\text { Radius of } \\
\text { cylinder } \\
\text { (angstroms) }\end{array}$ & $\begin{array}{l}\text { Diameter of } \\
\text { cylinder } \\
\text { (angstroms) }\end{array}$ \\
\hline \multicolumn{7}{|l|}{$\begin{array}{c}\text { Synthetic clinochrysotile, } \\
\text { T-2-29C }(\mathrm{F}-54) \text { : }\end{array}$} \\
\hline Record 1 - & 002 & 12.24 & 11.70 & 0.00942 & 97 & 194 \\
\hline Do & 004 & 24.50 & 23.98 & .00907 & 102 & 204 \\
\hline Record 1 - & 002 & 12.28 & 10.86 & .02478 & 37 & 74 \\
\hline Do--- & 004 & 24.60 & 23.60 & .01745 & 53 & 106 \\
\hline
\end{tabular}

microscopy. The electron microscopy of the synthetic clinochrysotile given by Bowen and Tuttle(1949) was also studied in more detail by us. Figure 49 shows that the sample consists of tubes of variable diameter ranging from 166 to $1,390 \mathrm{~A}$. Moreover, in photographs with magnifications of X 40,000 to X 50,000 , some tubes show a variability in diameter that is expressed as an apparent steeply tapered stepwise increase or decrease in diameter along the tube length. Bates (1958) observed this same structure and differentiated between two types described as "telescoped cylinders" and "cone-in-cone" structures in the synthetic preparation of Roy and Roy (1954). In electron micrographs of synthetic clinochrysotile of Bowen and Tuttle (1949) with a magnification of X 90,000 , these structures are resolved into spiral growth layers winding around the last completed inner tubular layer (fig. 50). At this magnification, the centers of the tubes appear to be right cylinders, and they appear to be empty.

The middle and upper parts of the tube marked $A$ (fig. 50) show a structure which may be interpreted as a poorly fitting spiral coil wound on a helical path on the outer surface of the tube with a flaring out of the coil at its top edge. The coiled sheet is assumed to be 10 layer units (about $73 \mathrm{~A}$ ) thick, and the very narrow ramplike surface formed by the spiraling edge of the sheet may be described as a helicoid. $A$ in figure 50 is oriented so that the spiral appears to be descending along the tube and, as it is wound in a clockwise fashion starting at the top of the coil, it is called a right-handed helicoid. ${ }^{4}$

The few helicoids in this photograph appear to be right-handed. The helical angle is about $9^{\circ}$. The

\footnotetext{
${ }^{4}$ The helicoid and related geometrical terms were defined by Schumann (1938) as follows: "The helicoid is a warped surface generated by a straight line moving so that it constantly touches a helix and its axis and makes a constant angle with that axis"(p. 281). "When the generatrix makes an angle of $90^{\circ}$ with the axis the helicoid is right" (p. 282). "When the generatrix makes an angle with the axis other than $90^{\circ}$ the helicoid is oblique" (p. 281). "A warped surface is one generated by a straight line moving so that no two consecutive positions lie in the same plane" (p. 261). [Italics added.]
}

structure marked $B$ (fig. 50 ) appears to be a series of helical growth layers forming incomplete spirals. Their staggering about the tube is probably related to periodic defects on the outer tube surface upon which they grow. These structures resemble the "cone-incone" structures of Bates (1958), but there is no trace of an internal cone. Conical terminations could arise as defect structures. The structure marked $C$ (fig. 50) shows bands growing on a central tube in telescopic fashion. Clinochrysotile tubes are probably limited in their diametral growth by the accumulation of defects along the edges of the spirals which curl and join to form tubes. When the defects become too numerous, the tube diameters cease to increase. Within short lengths of the tube, growth may still occur as oriented overgrowths, and in this manner the bands can form. The tapering at the edge of the bands is caused by the spiral growth. These structures give rise to abnormal fibril diameters. The radii of the tubes calculated from the X-ray data and shown in table 5 yield an average radius of $98 \mathrm{~A}$, or a cylinder diameter of $196 \mathrm{~A}$. A strict comparison of this value with the electron-microscope data is difficult, but it is obvious that the calculated values are an average for heterogenous size distribution. The synthetic clinochrysotile of Roy and Roy (1954) studied by Bates (1958) showed a similar variation, and Bates found inner radii of 25-50 A and outer radii of $110-450 \mathrm{~A}$ for their preparation. The studies reported here show that the broadening of the lines on the diffraction pattern of the synthetic clinochrysotile arises from the abundance of extremely thin tubes.

The calculated tube radii for the clinochrysotile from Currant Creek, Nev., based on diffractometer traces, yield an average radius of $45 \mathrm{~A}$ and a cylinder diameter of $90 \mathrm{~A}$. The electron micrograph of this sample shows two components. The first type consists of tubes with an average inner diameter of $52 \mathrm{~A}$ and an average outer diameter of $207 \mathrm{~A}$, which, by 


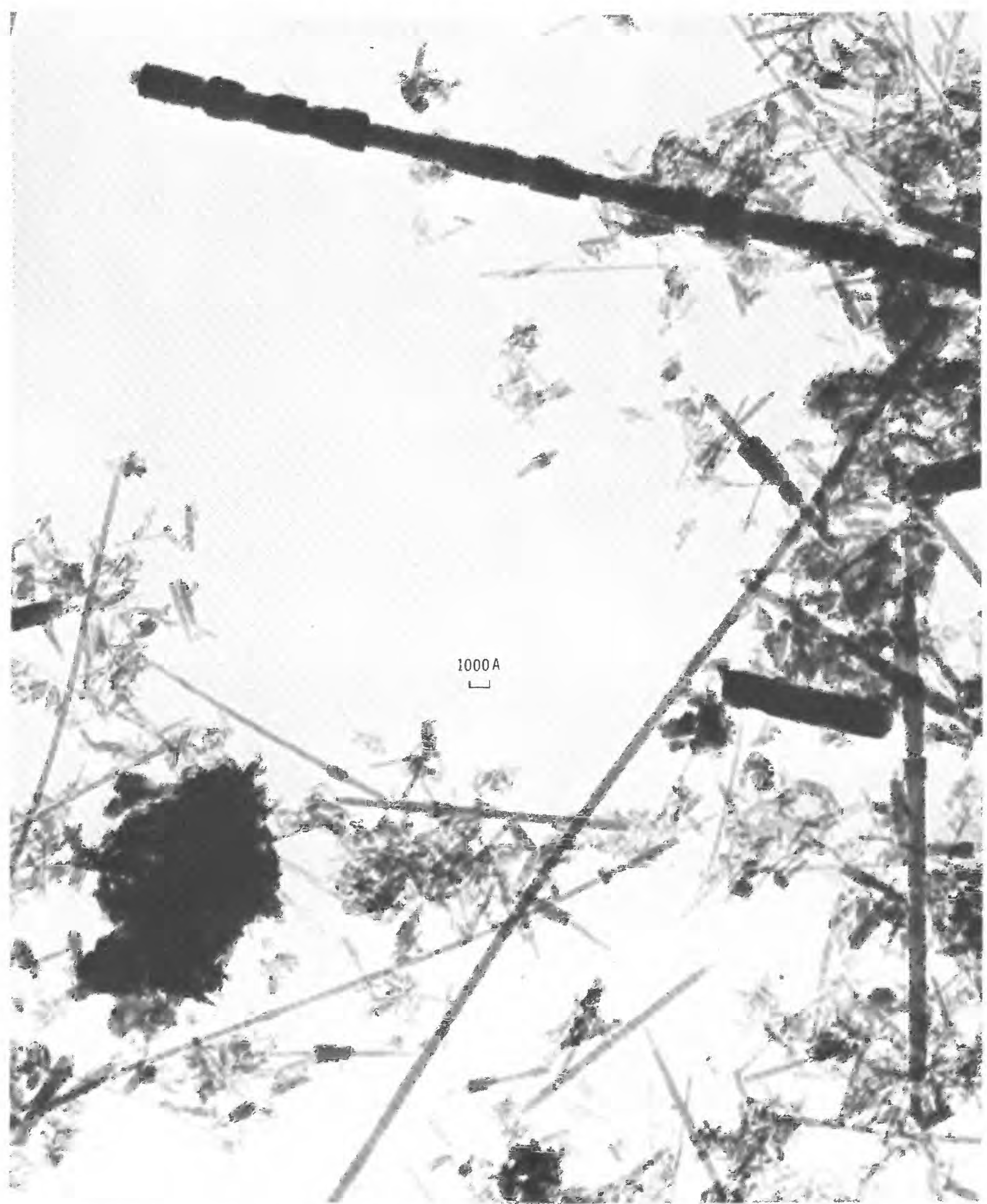

FIGURE 49.-Electron micrograph of the synthetic clinochrysotile of Bowen and Tuttle (1949). Note the tubular structure of the clinochrysotile and the much larger percentage of small tubes than of tubes having larger diameters. 


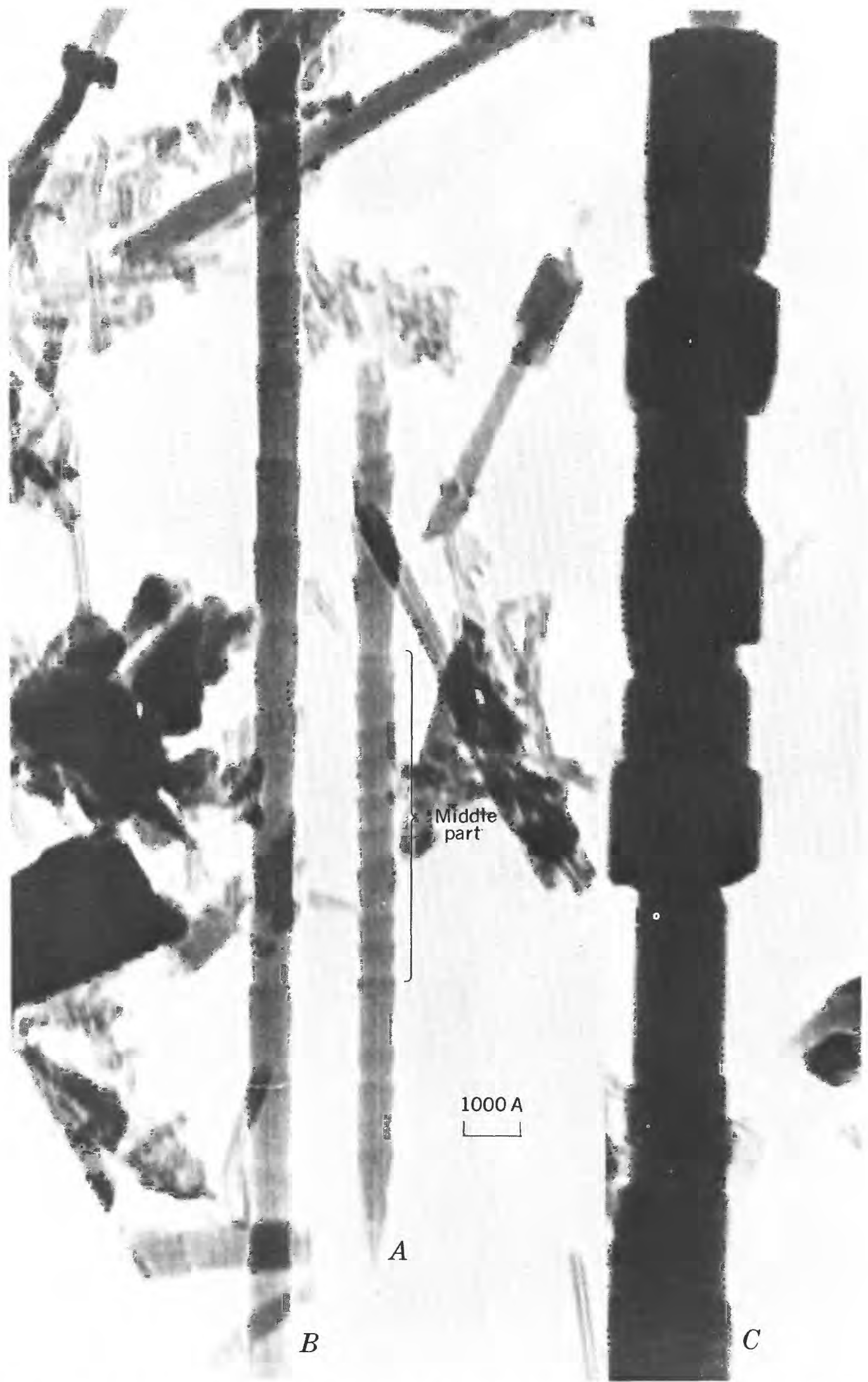

FIGURE 50--Electron micrograph of the synthetic clinochrysotile of Bowen and Tuttle (1949). A, a poorly fitting spiral coil wound on the middle part of the tube; $B$, a series of helical growth layers forming incomplete spirals; $C$ a band structure growing on the central tube in telescopic fashion. The proportion of the labeled structures is small relative to the amount of very fine tubes. 
difference, yields a wall thickness of $78 \mathrm{~A}$, or approximately 10 multiples of the layer unit. The second type consists of wisplike threads of extremely thin diameter. The radius calculated for this sample from line-broadening data is thus an average value for two different size fibers.

The similarity in the three X-ray powder patterns of pecoraite, the clinochrysotile from Nevada, and the synthetic clinochrysotile results from the presence in all of significant amounts of exceedingly fine particles. The size distribution in these three samples is, however, markedly different. In pecoraite, the size interval is small, and the coils and spirals are all short. In the synthetic clinochrysotile, even though there is a gradual change in tube diameter, the preponderant narrow tubes contribute greatly to the broadening of the line width on the Xray powder patterns. In the clinochrysotile from Nevada, there is a collection of rather closely sized tubes and an abundance of wisplike threads; the latter cause most of the broadening of the line widths.

INTERPRETATION OF TUBE MORPHOLOGY

The data in the literature on the dimensions of the tubular form of chrysotile are given in table 6 . These data have been derived from both electron-microscope and X-ray diffraction studies. The earlier work on fibril diameters is included to show agreement in the order of size with the later measurements and with Whittaker's (1957) theoretical calculation.

Whittaker (1957) calculated the number of layers of clinochrysotile which would be present in the tube wall. He found that the most common values for the inner and outer radii were 55 and $130 \mathrm{~A}$, respectively. The difference between these values is $75 \mathrm{~A}$, and this is 10 times one-half of the $c$ dimension of the unit cell $\left(\frac{c}{2}=7.32 \mathrm{~A}\right)$. He thus derived the multiple to be 10 .

The data in table 6 were used to calculate the number of layer multiples (col. 7) of the clinochrysotile in the walls of the tubes. Eleven sets of data in dicate the multiples to be six to 13 units, and eight of these are 9 to 11 units. Eight sets of data have multiples ranging from 17 to 24 units and averaging 20 units of clinochrysotile.

The comparison of data on inner and outer radii of tubular crystals of clinochrysotile obtained from electron micrographs and from low-angle scattering experiments by X-rays was criticized by Jagodzinski (1961, p. 314), who felt that the data obtained from electron-microscope techniques was of questionable value because of deformation in sample preparation. Yada (1967) therefore reexamined a clinochrysotile from Canada with a high-resolution electron micro. scope (table 6) and found little evidence for the dis tortion of the tubes in his method of preparation Yada (1967, p. 707) further found that:
*** the increment of the number of unit cells in the circumferential
direction is five for each additional layer of radial direction. As the
spacing of the observed radial fringes corresponds to the inter-
planar spacing of the $(020)$ plane, the corresponding increment of
radial fringes increases by 10 for each additional layer.

Jagodzinski (1961) found that the clinochrysotile from Poschiavo, Switzerland, contained 10 multiples of the layer unit of clinochrysotile in the tube walls, but using the same technique he also found multiples ranging from 17 to 24 for four other clinochrysotiles. Multiples of 20 to 23 were found by Kheiker, Flantsbaum, and Bubeleva (1967). Toman and Frueh (1968a,b) reinvestigated clinochrysotile and confirmed the earlier work of Whittaker (1957), which shows the number of multiples to be 10 . If 20 multiples is correct, then it may be explained by polytypism in clinochrysotile, or the larger multiple may arise from undetected oriented overgrowths occurring as long bands (fig. 50).

Whittaker's (1957) theoretical model for fibril diameters and for 10 multiples of the layer unit 7.3 $\mathrm{A}$ in the wall thickness is supported by the literature surveyed here. Yada's (1967) study also supports Whittaker's (1957) model. The data on wall thickness of pecoraite as determined in this study by electron microscopy (70 A) and by calculations from X-ray diffraction data (74 and $71 \mathrm{~A}$ ) are in accord with Whittaker's (1957) model of 10 multiples of the layer unit in the wall. The value of 20 multiples of the unit in the fibril wall needs further study. After this report had been completed, Yada (1971) published a contribution which shows cross sections of chrysotile tubes having single spiral, multispiral, and concentric structures. He also measured the frequency distribution of inner and outer diameters for six different chrysotile specimens and observed that the outer diameters may vary over a wide range in some specimens and that this variation in fibril diameter may vary from sample to sample.

The discrepancy between the various sets of data for the fibril diameters may arise from (1) the presence of tubes having variable outer diameters (tig. 49), (2) the presence of nriented overgrowths occurring as long bands (fig. 50 (), and (3) the phenomena observed by Maser, Rice, and Klug (1960) of chrysotile fibers consisting of tubes within tubes.

\section{CHEMICAL PROPERTIES}

PYROGNOSTICS

Pecoraite is slightly attacked by $1: 1 \mathrm{HCl}$ at room temperature, producing a bleaching of the color and a decrease in the mean index of refraction. Upon heating or boiling it decomposes, leaving a siliceous skeleton that has the same gross form as the individual mineral particles did before treatment with 
TABLE 6.-Fiber dimensions and wall thickness of chrysotile, synthetic chrysotile, and synthetic pecoraite derived from X-ray studies and electron microscopy

[Measurements are given in angstroms. avg., average]

\begin{tabular}{|c|c|c|c|c|c|c|c|c|}
\hline $\begin{array}{l}\text { Natural or } \\
\text { synthetic } \\
\text { phase }\end{array}$ & Locality or source & $\begin{array}{l}\text { Inner radius } \\
\text { of tubes }\end{array}$ & $\begin{array}{l}\text { Outer radius } \\
\text { of tubes }\end{array}$ & $\begin{array}{c}\text { Fibril } \\
\text { diameter }\end{array}$ & $\begin{array}{l}\text { Wall } \\
\text { thickness }\end{array}$ & $\begin{array}{l}\text { Approximate number } \\
\text { of multiples of layer } \\
\text { thickness }(=7.3 \mathrm{~A})\end{array}$ & Method & Observers \\
\hline Chrysotile --.---- & Thetford, Quebec, Canada- & $\cdots+\cdots$ & -..--... & 195 & $\ldots$ & -.- & $\begin{array}{l}\text { X-ray, low-angle } \\
\text { scattering. }\end{array}$ & $\begin{array}{l}\text { Fankucken and } \\
\text { Schneider (1944). }\end{array}$ \\
\hline $\begin{array}{l}\text { Chrysotile } \\
\text { (harsh). }\end{array}$ & United States & - & -.-.-.. & 250 & -. & -.. & -o-do----.. & Do. \\
\hline $\begin{array}{l}\text { Chrysotile } \\
\text { (soft). }\end{array}$ & 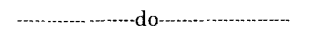 & -...-.-. & ...-.... & 226 & $\ldots$ & $\ldots$ & -..--do--.-- & Do. \\
\hline Chrysotile .......... & Italy & ........ & ........ & 218 & -.. & $\ldots$ & 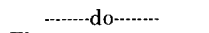 & Do. \\
\hline Chrysotile …....... & Kings, Canada- & $-y_{-1}$ & ---.-. & 100 & $\cdots$ & $\cdots$ & $\begin{array}{l}\text { Electron } \\
\text { microscopy. }\end{array}$ & $\begin{array}{l}\text { O'Daniel and } \\
\text { Kedesdy (1947). }\end{array}$ \\
\hline Chrysotile ........... & - nen & -..--- & -..-... & 180 & $\cdots$ & 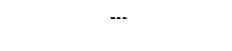 & 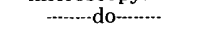 & $\begin{array}{c}\text { Turkevich and } \\
\text { Hillier (1949). }\end{array}$ \\
\hline Chrysotile .......... & $\begin{array}{l}\text { Natal Province, } \\
\text { Union of South Africa. }\end{array}$ & 90 & 170 & -- & 80 & 11 & $\begin{array}{l}\mathrm{X} \text {-ray, low-angle } \\
\text { scattering. }\end{array}$ & $\begin{array}{l}\text { Jagodzinski and } \\
\quad \text { Kunze }(1954 a, b, c ; 1956) .\end{array}$ \\
\hline Chrysotile .......... & Canada & 130 & -..---.- & -- & $\ldots$ & $\ldots$ & 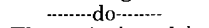 & Do. \\
\hline Chrysotile -..--..-- & 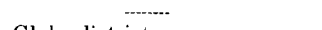 & 55 avg. & 130 avg. & -- & 75 & 10 & Theoretical model-- & Whittaker (1957). \\
\hline Chrysotile ------- & $\begin{array}{l}\text { Globe district, } \\
\text { Arizona. }\end{array}$ & 25 & 65 & $\cdots$ & 40 & 6 & $\begin{array}{l}\text { Electron } \\
\text { microscopy. }\end{array}$ & Bates [1958]. \\
\hline Chrysotile -.....-- & $\begin{array}{l}\text { Synthetic of } \\
\text { Roy and Roy (1954). }\end{array}$ & $25-50$ & $100-450$ & - & $\cdots$ & $--\cdot$ & 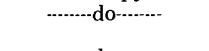 & Do. \\
\hline Chrysotile ........... & Synthetic- & 37 & 120 & -- & 83 & 11 & -do-............ & $\begin{array}{l}\text { Noll, Kircher, and } \\
\text { Sybertz (1958). }\end{array}$ \\
\hline $\begin{array}{l}\text { Nickel } \\
\text { chrysotile. }\end{array}$ & Synthetic pecoraite & 45 & 109 & $\cdots$ & 64 & 9 & -......-do-n-...... & Do \\
\hline Chrysotile -......... & $\begin{array}{l}\text { Madison County, } \\
\text { Montana. }\end{array}$ & $50-88$ & $182-220$ & -.- & $\cdots$ & $\ldots$ & ........................ & $\begin{array}{l}\text { Bates and Comer } \\
\text { (1959). }\end{array}$ \\
\hline Chrysotile -......... & $\begin{array}{l}\text { Globe district, } \\
\text { Arizona. }\end{array}$ & 10-95, & $57-425$, & ..- & $\cdots$ & $\cdots$ & 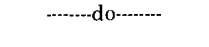 & Do. \\
\hline Chrysotile -...-...... & $\begin{array}{l}\text { Thetford, } \\
\text { Quebec, Canada. }\end{array}$ & mean 34 & mean 125 & $\cdots-$ & 91 & 13 & 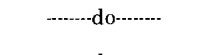 & Do. \\
\hline $\begin{array}{l}\text { Chrysotile } \\
\text { (silky fibers) }\end{array}$ & $\begin{array}{l}\text { Transvaal, } \\
\text { Union of South Africa. }\end{array}$ & $\cdots+-$. & -.----. & $\left\{\begin{array}{l}1340 \\
280\end{array}\right.$ & $\begin{array}{l}40 \\
70\end{array}$ & $\left.\begin{array}{c}6 \\
10\end{array}\right\}$ & 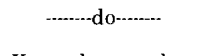 & $\begin{array}{l}\text { Maser, Rice, and } \\
\text { Klug (1960). }\end{array}$ \\
\hline $\begin{array}{l}\text { Chrysotile } \\
\text { (brittle). }\end{array}$ & $\begin{array}{l}\text { Poschiavo, Grisons Canton, } \\
\text { Switzerland. }\end{array}$ & $175 \pm 5$ & $248 \div 5$ & $\cdots$ & 73 & 10 & $\begin{array}{l}\text { X-ray, low-angle } \\
\text { scattering. }\end{array}$ & Jagodzinski (1961). \\
\hline Chrysotile -.........- & $\begin{array}{l}\text { Transvaal, } \\
\text { Union of South Africa. }\end{array}$ & ......... & -.......- & -- & 124 & 17 & -.........do--..... & Do. \\
\hline $\begin{array}{l}\text { Chrysotile -...-...-. } \\
\text { Chrysotile -...... }\end{array}$ & $\begin{array}{l}\text { New York (?) } \\
\text { Quebec Canada (?) }\end{array}$ & $\cdots+\cdots$ & 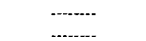 & $\overline{-}$ & 132 & $\begin{array}{l}18 \\
20\end{array}$ & 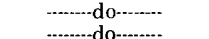 & Do. \\
\hline Chrysotile -.--..-..- & $\begin{array}{l}\text { Quebec, Canada (?) } \\
\text { Thetford, } \\
\text { Quebec, Canada. }\end{array}$ & -...-..- & -..-.... &.- & 180 & 24 & ....................... & $\begin{array}{l}\text { Do. } \\
\text { Do. }\end{array}$ \\
\hline Chrysotile -........... & $\begin{array}{c}\text { Bazhenovo, S. Sverdlovsk } \\
\text { oblast, Russia (normal). }\end{array}$ & 25 & 170 & $\cdots$ & 145 & 20 & 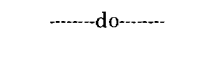 & $\begin{array}{l}\text { Kheiker, } \\
\text { Flantsbaum, and } \\
\text { Bubeleva (1967) }\end{array}$ \\
\hline Chrysotile -......... & Kiembai, U.S.S.R. & 30 & 190 & ... & 160 & 22 & ....................... & Do. \\
\hline Chrysotile -...-..... & Ak-Tovrak, U.S.S.R.-......... & 25 & 195 & -.. & 170 & 23 & -.-.-do--..-- & Do. \\
\hline Chrysotile -........ & Dzhetygara, U.S.S.R. & 35 & 192 & $\cdots$ & 157 & 21 & 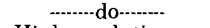 & Do. \\
\hline Chrysotile -..---.- & $\begin{array}{l}\text { Jeffrey Mine, } \\
\text { Asbestos, Canada. }\end{array}$ & $25-40$ & $\begin{array}{l}75-500 \\
\text { avg. } 250\end{array}$ & --- & -- & $\cdots$ & $\begin{array}{l}\text { High-resolution } \\
\text { electron } \\
\text { microscopy. }\end{array}$ & Yada (1967). \\
\hline Chrysotile -..--..-. & $\begin{array}{l}\text { Average of (15) specimens: } \\
\text { Quebec, Canada (9) } \\
\text { British Columbia, Canada (1) } \\
\text { Australia (3) } \\
\text { Russia (1) } \\
\text { Arizona (1) }\end{array}$ & 1) & 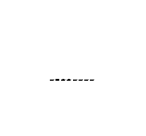 & 234 (mean) & 77 & 10 & X-ray-..-..-......... & $\begin{array}{l}\text { Toman and } \\
\text { Frueh }(1968 \mathrm{a}, \mathrm{b}) \text {. }\end{array}$ \\
\hline
\end{tabular}

${ }^{1}$ Average of outer tubes.

Average of inner tubes.

acid. Pecoraite yields water when heated in a closed tube.

\section{CHENICAL ANAI YSIS AND COMPOSITION}

The chemical analysis (table 7) was made on 0.1044 g of concentrate. The oxides other than $\mathrm{H}_{2} \mathrm{O}$ were determined on the residue which remained after the dehydration study. The dehydration data, when plotted as a thermal-analysis curve (fig. 51), failed to show a change in direction which would indicate that all the adsorbed water had been driven off at a low temperature. The X-ray powder pattern indicated a chrysotilelike structure, which was confirmed by the $\mathrm{NiO}-\mathrm{SiO}_{2}$ ratio of $3: 2$ in the analysis. Therefore, only 9.7 percent of the total (13.8 percent) water in the analysis is combined water. This adjustment gave a $\mathrm{NiO}-\mathrm{SiO}_{2}-\mathrm{H}_{2} \mathrm{O}$ ratio of 3:2:2 for the nickel analog of chrysotile, pecoraite.
Assuming the structural formula for pecoraite to be $\mathrm{Ni}_{6} \mathrm{Si}_{4} \mathrm{O}_{10}(\mathrm{OH})_{8}$ and using the equivalent weights for the oxides and the method of calculation given by Faust and Fahey (1962, p. 27, 32), the structural formula is computed from the analyses to be:

$$
\begin{array}{cc}
{\left[\mathrm{Ni}_{5.41} \mathrm{Mg}_{0.10} \mathrm{Fe}^{+2}{ }_{0.08} \mathrm{Al}_{0.22}\right]\left[\mathrm{Si}_{4.05}\right] \mathrm{O}_{10}(\mathrm{OH})_{8}} \\
\underset{\text { oct }}{\sum=5.81} & \underset{\text { tet }}{\sum=4.05}
\end{array}
$$

Theoretically, pecoraite should have 6.00 ions in octahedral coordination and 4.00 ions in tetrahedral coordination, but bearing in mind the small size of the sample and the low summation of the analysis, the agreement between theory and experiment is very good. The indicated discrepancy in the filling of octahedral sites is probably not real. 
TABLE 7.-Chemical analysis of pecoraite from the Wolf Creek meteorite, Wolf Creek, Australia

[Analyst, Joseph J. Fahey]

\begin{tabular}{|c|c|c|c|c|c|}
\hline & Percentage & $\begin{array}{c}\text { Molecular } \\
\text { weight }\end{array}$ & $\begin{array}{c}\text { Mole } \\
\text { number }\end{array}$ & $\begin{array}{l}\text { Mole } \\
\text { ratio }\end{array}$ & $\begin{array}{l}\text { Theoretical } \\
\text { composition }\end{array}$ \\
\hline $\begin{array}{l}\mathrm{SiO}_{2} \\
\mathrm{NiO} \\
\mathrm{FeO}- \\
\mathrm{MgO}- \\
\mathrm{Al}_{2} \mathrm{O}_{3} \\
\mathrm{H}_{2} \mathrm{O}+\text { (combined) } \\
\mathrm{H}_{2} \mathrm{O} \text { - (adsorbed)- } \\
\mathrm{CaO}- \\
\mathrm{MnO}-\end{array}$ & $\begin{array}{r}31.0 \\
51.5 \\
.7 \\
.5 \\
1.4 \\
9.7 \\
4.1 \\
.4 \\
.0\end{array}$ & $\begin{array}{c}60.09 \\
74.71 \\
71.85 \\
40.32 \\
101.96 \\
18.02 \\
\cdots \\
\cdots-\end{array}$ & $\left.\begin{array}{c}0.5159 \\
.6893 \\
.0097 \\
.0124 \\
.0137 \\
.5383 \\
\cdots- \\
\cdots \\
\cdots\end{array}\right\} 0.7251$ & $\begin{array}{c}2.0=2 \\
2.9=3 \\
2.1=2 \\
\cdots \cdots \\
\cdots \cdots\end{array}$ & $\left\{\begin{array}{c}31.60 \\
58.92 \\
\cdots- \\
\cdots- \\
9.48 \\
\cdots \cdots \\
\cdots \\
\cdots\end{array}\right.$ \\
\hline$\Sigma$ & 99.3 & $\cdots$ & -.- & -- & 100.00 \\
\hline
\end{tabular}

MICROPROBE INAIYSIS

Specimens of pecoraite were analyzed by means of a microprobe by Mason, who found $\mathrm{SiO}_{2} \approx 30$ percent, $\mathrm{NiO} \approx 55$ percent, and $\mathrm{FeO}, \mathrm{MgO}, \mathrm{CaO}$, and $\mathrm{Al}_{2} \mathrm{O}_{3}$ all equal to or less than the background-approximately less than 0.5 percent. Considering the small chemical variability within the sample and the difference in the size of the samples used for chemical and microprobe analysis, the results are in good agreement.

The actual variation in the distribution of nickel and iron in individual grains of pecoraite was investigated with the electron probe by Dwornik, who found that nickel oxide ranged from 50.4 to 52.6 percent, and the iron, from 0.0 to approximately 0.5 percent. Phosphorus was not detected in the analyzed sample, which indicates the total absence of the phosphate minerals lipscombite, cassidyite, and apatite.

\section{STUDIES ON PECORAITE AND RELATED SYNTHETIC PHASES IN THE SYSTEM $\mathrm{H}_{2} \mathrm{O}-\mathrm{NiO}-\mathrm{SiO}_{2}$}

Feitknecht and Berger (1942) heated a suspension of carefully purified nickel hydroxide in a glass tube bomb at about $200^{\circ} \mathrm{C}$ and obtained a pale-green product that gave an X-ray pattern resembling that of a synthetic serpentine-group mineral. The X-ray powder data obtained on this material are given in table 4 . The $d$-spacings were computed by Brindley (1961) from the original measurement of Feitknecht and Berger. To obtain the chemical composition of this synthetic mineral, Feitknecht and Berger (1942) digested the green product, which contained unreacted nickelous oxide and possibly other materials, in hydrochloric acid; the analysis of the product is given in table 8 , along with the theoretical composition of pecoraite. The chemical analysis and the X-ray data of Feitknecht and Berger (1942) show that this product is a mixture of a serpentine-group mineral and silica. The presence of siliceous plates and flakes in the products of solution studies on phyllosilicates is now well known, and it can account for the discord between the chemistry and X-ray study of Feitknecht and Berger (1942). Longuet (1947) prepared a nickel serpentine, which was called nickel antigorite, and gave X-ray powder diffraction data in support of the synthesis (table 4).

Hydrous nickel silicates were also synthesized by van Voorthuijsen and Franzen $(1950,1951)$, who boiled solutions of nickel nitrate and alkali metasilicates to produce gels. X-ray studies showed these gels to yield "rather vague" patterns resembling those of phyllosilicates. Further heating of these gels at $250^{\circ} \mathrm{C}$ for 50 hours yielded "well-defined" hydrous nickel silicates. Examination of these products by Xray diffraction, electron diffraction, and thermal analysis showed the presence of a nickel serpentine group mineral and pimelite (synthetic nickel montmorillonite).

Noll and Kircher (1952) synthesized nickel chrysotile from solutions of nickel chloride, water glass, and sodium hydroxide held in a hydrothermal bomb for 3 hours at $300^{\circ} \mathrm{C}$ at a water-vapor pressure of 87 $\mathrm{kg} / \mathrm{cm}^{2}$ (84 atms). The X-ray powder photographs showed the phase to be a chrysotile type, and the electron-microscope photographs showed the characteristic tubular structure of chrysotile. Comparison of the studies on this material with similar studies on "garnierite" from Noumea, New Caledonia, by Noll and Kircher (1952) demonstrated the morphologic identity of their product with one of the phases in the natural "garnierite."

Using coprecipitated gels, Roy and Roy (1954) synthesized phases in the system $\mathrm{H}_{2} \mathrm{O}-\mathrm{NiO}-\mathrm{SiO}_{2}$ by hydrothermal methods in the temperature range of $220^{\circ} \mathrm{C}$ to $500^{\circ} \mathrm{C}$ and at pressures ranging from 5,000 to $10,000 \mathrm{psi}$ ( 340 to $680 \mathrm{atms}$ ) for periods ranging from 24 to 215 hours. They observed in the electron microscope good tubes and very fine plates. On the basis of their X-ray powder diffraction data (table 4) and their electron-microscope photographs, they concluded that their products contained a nickel serpentine.

TABLE 8.-Chemical analyses of some synthetic products related to or containing pecoraite

[Analyst, Dr. O. Steinhauser]

Pale-green product Synthetic pecoraite Synthetic pecoraite

(Feitknecht and of Noll, Kircher, and of Noll, Kircher, and Theoretical Berger, 1942) Sybertz (1960) Sybertz recalculated pecoraite omitting $\mathrm{H}_{2} \mathrm{O}^{-}$

\begin{tabular}{|c|c|c|c|c|}
\hline $\left.\begin{array}{l}\mathrm{SiO}_{2} \\
\mathrm{NiO} \\
\mathrm{H}_{2} \mathrm{O}+ \\
\mathrm{H}_{2} \mathrm{O}-\end{array}\right\}$ & $\begin{array}{l}47.5 \\
37.3 \\
13.7\end{array}$ & $\begin{array}{r}28.8 \\
55.3 \\
10.2 \\
5.2\end{array}$ & $\begin{array}{l}30.5 \\
58.7 \\
10.8 \\
\cdots-.\end{array}$ & $\begin{array}{c}31.60 \\
58.92 \\
9.48 \\
-.-\end{array}$ \\
\hline$\sum$ & 98.5 & 99.5 & 100.0 & 100.00 \\
\hline
\end{tabular}


Noll, Kircher, and Sybertz (1958) proposed that chrysotile, nickel chrysotile, and "halloysite" be designated "solensilicates" because of their characteristic tubelike habit and that this be a subgroup of the phyllosilicate group of the Strunz classification $(1938,1966)$. They added data on tube diameters, tube lengths, and absorption characteristics and detailed electron-microscope studies. The electron-microscope photographs leave no doubt as to their conclusion that they synthesized nickel chrysotile (=synthetic pecoraite). Noll, Kircher, and Sybertz (1960) published further data on the nickel chrysotile (=synthetic pecoraite). They gave its color as light green, its mean index of refraction for sodium light as 1.654, and its chemical analysis (table 8). Recalculation of this analysis omitting $\mathrm{H}_{2} \mathrm{O}$ - gives a good agreement with the theoretical formula.

Kozyrin, Bezrukov, Gusel'nikov, and Litvin (1968) apparently synthesized both pecoraite and another phase, as suggested by their electron micrographs.

The work of Noll and Kircher (1952), Noll, Kircher, and Sybertz (1958), and Roy and Roy (1954) shows the existence of nickel chrysotile, which is the synthetic equivalent of pecoraite.

\section{THERMAL-ANALYSIS STUDIES STATIC (DEHYDRATION) METHOD}

The sample of pecoraite picked for the chemical analysis was also used for the dehydration study. It was heated in a platinum crucible in a furnace thermostated to a given temperature until its weight approached constancy. It was removed from the furnace after a given period of time, placed in a dessicator, and then weighed. The results of these heatings and weighings are given in table 9 and are plotted to give the curve in figure 51 . This curve is similar to the curve for clinochrysotile from Quebec, Canada (F-10), in Faust and Fahey (1962).

DYNAMIC (DIFFERENTIAL-THERMAL-ANALYSIS) METHOD

Differential thermal analyses were made on impure samples of pecoraite by the techniques described by Faust $(1948,1950)$. The samples were heated in air at the rate of $10^{\circ} \mathrm{C}$ per minute. The records were obtained as photographs. Because of the scarcity of purified material, the DTA (differential-thermalanalysis) records were obtained on partly purified samples which contained only a small amount of pecoraite, significant quantities of adsorbed water, and a small amount of organic matter. The loss of this adsorbed water produced a broad, low, temperature endotherm (fig. 52). The trough representing the decomposition of pecoraite is broad for a serpentine-group mineral, and its shape is attributed to the fine grain size of the particles. The

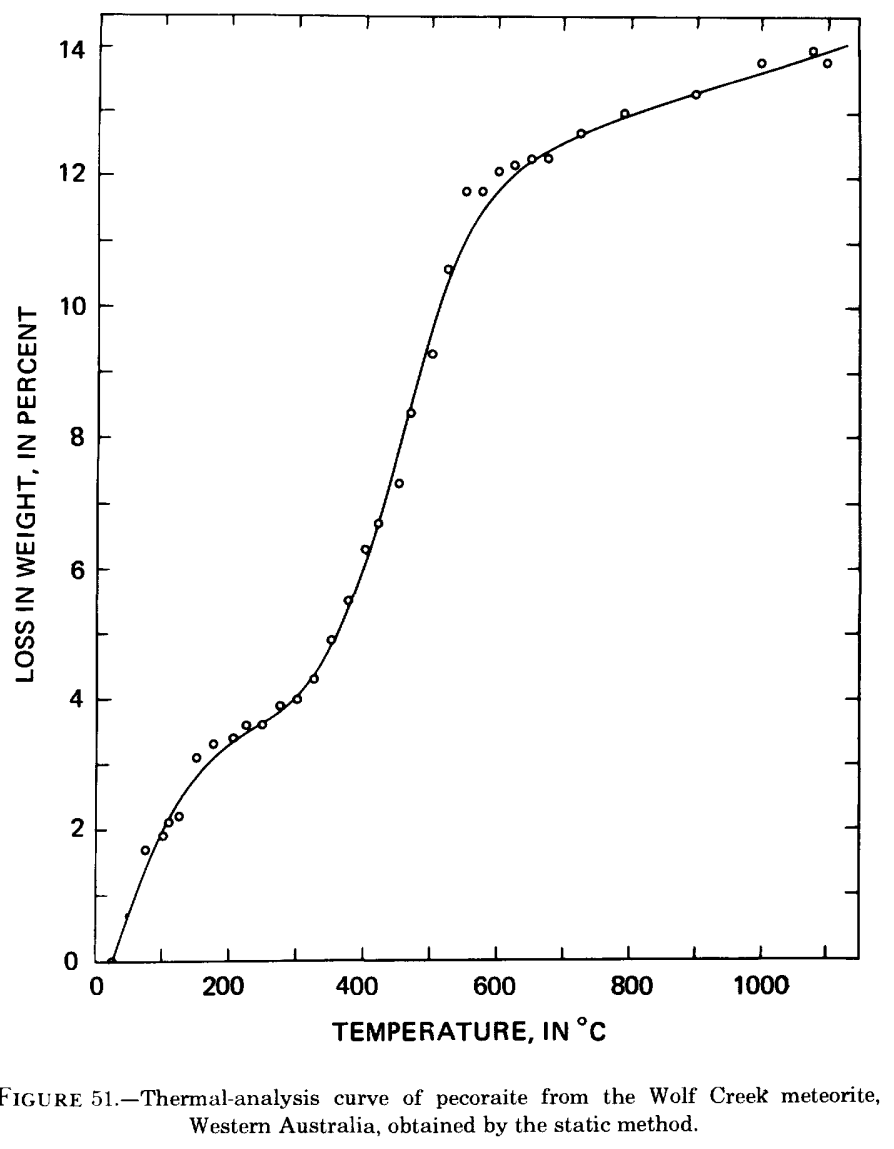

temperature of this trough is $562^{\circ} \mathrm{C}$ on record C-988 and $575^{\circ} \mathrm{C}$ on record $\mathrm{C}-961$, which has a broader endotherm. The exothermic reaction in the temperature range of about $250^{\circ} \mathrm{C}$ to $475^{\circ} \mathrm{C}$ is probably due chiefly to admixed maghemite and, to a lesser extent, to organic matter, some of which may have been introduced in the process of concentrating the pecoraite. The absence of goethite in these partly purified materials is evidenced by the lack of an endotherm in the range of $350^{\circ} \mathrm{C}$ to $400^{\circ} \mathrm{C}$.

\section{DISINTEGRATION OF THE WOLF CREEK METEORITE AND THE FORMATION OF PECORAITE}

\section{TIME, TEMPERATURE, AND PRESSURE RELATIONS OF THE NATURAL SYSTEM}

To determine the probable origin of pecoraite, it is first necessary to evaluate the time, temperature, and pressure relations of the Wolf Creek meteorite in its earthly environment. Shortly after its impact with the earth, the fragmented meteorite was exposed to the agencies of disintegration-the heat of the sun, the atmosphere, and the occasional torrential rains.

The meteorite fragments are now in sedimentary material, which consists of a superficial layer of sand 1 to 2 feet thick that overlies a Tertiary laterite that 
TABLE 9.-Thermal-analysis data obtained by the static method on pecoraite from the Wolf Creek meteorite, Western Australia [Dehydration made on 0.1044-gram sample]

\begin{tabular}{|c|c|c|c|c|}
\hline $\begin{array}{c}\text { Temperature } \\
\left({ }^{\circ} \mathrm{C}\right)\end{array}$ & $\begin{array}{c}\text { Weight loss } \\
\text { (grams, } \pm 0.0002 \text { ) }\end{array}$ & $\begin{array}{c}\text { Cumulative } \\
\text { weight loss } \\
\text { (percent) }\end{array}$ & $\begin{array}{c}\text { Change in } \\
\text { weight loss } \\
\text { (percent) }\end{array}$ & $\begin{array}{r}\Delta T \\
\left({ }^{\circ} \mathrm{C}\right)\end{array}$ \\
\hline 25 & 0.0000 & ... & - & - \\
\hline 77 & .0018 & 1.72 & 1.72 & 52 \\
\hline 101 & .0020 & 1.92 & .20 & 24 \\
\hline 110 & .0022 & 2.11 & .19 & 9 \\
\hline 125 & .0023 & 2.20 & .09 & 15 \\
\hline 150 & .0032 & 3.07 & .87 & 25 \\
\hline 174 & .0034 & 3.27 & .20 & 24 \\
\hline 205 & .0035 & 3.35 & .08 & 31 \\
\hline 225 & .0038 & 3.64 & .29 & 20 \\
\hline 250 & .0038 & 3.64 & .0 & 25 \\
\hline 275 & .0041 & 3.93 & .29 & 25 \\
\hline 300 & .0042 & 4.02 & .09 & 25 \\
\hline 325 & .0045 & 4.31 & .09 & 25 \\
\hline 350 & .0051 & 4.89 & .58 & 25 \\
\hline 375 & .0057 & 5.46 & .57 & 25 \\
\hline 400 & .0066 & 6.32 & .86 & 25 \\
\hline 420 & .0070 & 6.70 & .38 & 20 \\
\hline 450 & .0076 & 7.28 & .58 & 30 \\
\hline 470 & .0088 & 8.43 & 1.15 & 20 \\
\hline 500 & .0097 & 9.29 & .86 & 30 \\
\hline 525 & .0111 & 10.63 & 1.34 & 25 \\
\hline 550 & .0199 & 11.40 & .77 & 25 \\
\hline 575 & .0123 & 11.78 & .38 & 25 \\
\hline 600 & .0126 & 12.07 & .29 & 25 \\
\hline 625 & 0127 & 12.16 & .09 & 25 \\
\hline 650 & .0128 & 12.26 & .10 & 25 \\
\hline 675 & .0128 & 12.26 & .0 & 25 \\
\hline 725 & .0133 & 12.74 & .48 & 50 \\
\hline 790 & .0136 & 13.03 & .29 & 65 \\
\hline 900 & .0139 & 13.31 & .28 & 110 \\
\hline 1,000 & .0144 & 13.79 & .48 & 100 \\
\hline 1,080 & .0146 & 13.98 & .19 & 80 \\
\hline 1,100 & .0144 & 13.79 & -.19 & 20 \\
\hline
\end{tabular}

has a typical coarse pisolitic structure. The laterite layer is about 10 to 20 feet thick. Most specimens of the meteorite that have been collected are from the outer surface of the crater mound.

The time span during which the alteration of the Wolf Creek meteorite has taken place has been estimated to be at least a million years by McCall (1965, p. 991), who stated: "The morphological state of the crater probably limits the possible age to Pliocene or at the very latest to Plio-Pleistocene."

The temperature of the environment is that of a desert in a tropical region. It is hot during the day and cool at night. Mason (1968), during his field trip to the Wolf Creek crater, observed that the nights, though cool, were dew free, and that, consequently, frosts do not occur. He noted also that torrential rains occur only during the monsoon season.

The Commonwealth Bureau of Meteorology makes observations at Halls Creek and at Balgo Mission, and some of their data are given in Casey and Wells (1964). The average annual rainfall of 12 inches near Wolf Creek occurs during the northwest's monsoon season, but some rain falls during the winter because of the influence of the southern Australian weather. At Balgo Mission the mean maximum air temperatures range from $25.9^{\circ} \mathrm{C}\left(78.6^{\circ} \mathrm{F}\right)$ in July to $39.9^{\circ} \mathrm{C}\left(103.8^{\circ} \mathrm{F}\right)$ in December; correspondingly, the mern minimum temperatures range from $11.9^{\circ} \mathrm{C}$ $\left(53.5^{\circ} \mathrm{F}\right)$ to $25.7^{\circ} \mathrm{C}\left(78.2^{\circ} \mathrm{F}\right)$. In an area close to the Wolf Creek crater, Roberts, Halligan, and Playford (1969) reported an average annual rainfall of 16 inches in the south and 20 inches in the north. The daily maximum air temperature in January is $38^{\circ} \mathrm{C}$ $\left(100^{\circ} \mathrm{F}\right)$, and the minimum is $24^{\circ} \mathrm{C}\left(75^{\circ} \mathrm{F}\right)$; in July the values are $27^{\circ} \mathrm{C}\left(80^{\circ} \mathrm{F}\right)$ and $10^{\circ} \mathrm{C}\left(50^{\circ} \mathrm{F}\right)$, respectively. Probably because of its lower elevation, the air temperatures at the Wolf Creek crater are appreciably higher than those at Balgo Mission.

Cassidy (1954) observed that the "vegetation inside the crater is much more luxuriant than outside, reflecting the rain-catching propensity of the great bowl."

For this study, we felt that something should be known of the temperature variations in the meteorite during an average day. To assess these variations the diurnal and nocturnal temperature variations, both in the atmosphere and in the ground below it, must also be known. Such data do not exist for the Wolf Creek crater, however, so they were estimated from studies made in other deserts.

Observations of the air temperatures and of the temperatures in the ground were made by Sinclair (1922) at the Desert Laboratory, Carnegie Institution of Washington, near Tucson, Ariz. Some of these data were replotted by Brinkmann in Kayser (1967), and his diagram is given in figure 53 . The measurements were taken from $175 \mathrm{~cm}$ above the ground to $200 \mathrm{~cm}$ below the surface. The temperature curve demonstrates the character of a single cycle to a depth of 50 $\mathrm{cm}$, below which the contribution from solar heat becomes minimal. The minimum temperature of the air above the surface $(25 \mathrm{~cm})$ was $10^{\circ} \mathrm{C}\left(50^{\circ} \mathrm{F}\right)$, and the maximum was about $48^{\circ} \mathrm{C}\left(118^{\circ} \mathrm{F}\right)$; at the ground surface the minimum and maximum temperatures were $17.5^{\circ} \mathrm{C}\left(64^{\circ} \mathrm{F}\right)$ and $72^{\circ} \mathrm{C}\left(162^{\circ} \mathrm{F}\right)$, respectively. At $50-\mathrm{cm}$ depth the curves form a cusp point, at approximately $28^{\circ} \mathrm{C}\left(82^{\circ} \mathrm{F}\right)$, at which the two curves touch but through which they do not pass. The curve

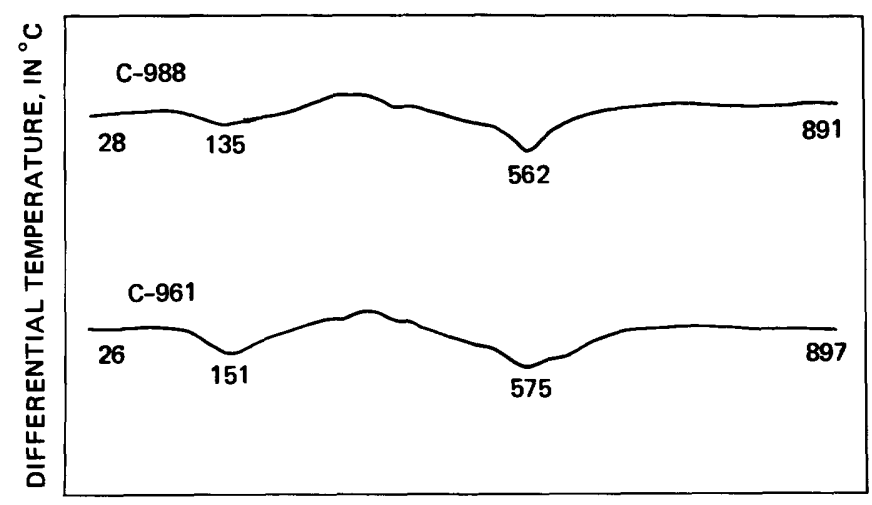

INCREASING TEMPERATURE, IN ${ }^{\circ} \mathrm{C}$

FIGURE 52.-Differential-thermal-analysis curves of a partly purified sample of pecoraite from the Wolf Creek meteorite of Australia. Resistance of $600 \mathrm{ohms}$ in the galvanometer circuit. 
shows the notable temperature change of the air, $\Delta T=38^{\circ} \mathrm{C}\left(97^{\circ} \mathrm{F}\right)$, and the exceptionally larger ground-surface temperature variations, $\Delta T=55^{\circ} \mathrm{C}$ $\left(131^{\circ} \mathrm{F}\right)$. Hörner $(1936,1957)$, gave similar data for the region of Etsin Gol, Gobi Desert, central Asia. For June 6, 1932, the minimum air temperature was about $18^{\circ} \mathrm{C}\left(64^{\circ} \mathrm{F}\right)$, and the maximum, about $35^{\circ} \mathrm{C}$ $\left(95^{\circ} \mathrm{F}\right) ; 2 \mathrm{~mm}$ below the surface the minimum was about $8^{\circ} \mathrm{C}\left(46^{\circ} \mathrm{F}\right)$, and the maximum, about $58^{\circ} \mathrm{C}$ $\left(136^{\circ} \mathrm{F}\right)$. Fifty centimeters below the surface, temperature was almost constant at $18^{\circ} \mathrm{C}\left(64^{\circ} \mathrm{F}\right)$. Likewise, Dubief (1959, p. 90) gave for Touggart, Sahara Desert, North Africa, data for July 6, 1931, as follows: Close to the surface the minimum was $24^{\circ} \mathrm{C}$ $\left(75^{\circ} \mathrm{F}\right)$, and the maximum, $58^{\circ} \mathrm{C}\left(136^{\circ} \mathrm{F}\right) ; 10 \mathrm{~cm}$ below the surface the minimum was $34^{\circ} \mathrm{C}\left(93^{\circ} \mathrm{F}\right)$, and the maximum, $41^{\circ} \mathrm{C}\left(106^{\circ} \mathrm{F}\right) ; 20 \mathrm{~cm}$ below the surface the minimum was $34^{\circ} \mathrm{C}\left(93^{\circ} \mathrm{F}\right)$, and the maximum, $36^{\circ} \mathrm{C}$ $\left(97^{\circ} \mathrm{F}\right)$. For similar depths these several sets of data are comparable. Superimposed upon the daily variation is the annual regional variation (seasonal variation) which for the tropics results in lower temperatures in the rainy season and higher temperatures in the dry season; data for these observations are contained in the works cited above. These data suffice to illustrate typical temperature conditions in world deserts.

To assess the probable conditions in the desert area of the Wolf Creek crater, we may compare the contours of the total thermal energy reaching the horizontal surface of the earth at Wolf Creek; Tucson, Ariz.; Gobi; and the Sahara, as given by Budyko (1958). The Wolf Creek area receives a total thermal energy of about 180 kilolangleys ${ }^{5}$ per year; the Tucson area receives 180-200 kilolangleys per year; the Sahara, 180-200 kilolangleys per year; and the Gobi, about 140-160 kilolangleys per year. We may. therefore, use the more complete data of Sinclair (1922) from the Tucson area as those representative of the probable conditions at Wolf Creek.

The external pressure of the environment in which the meteorite lay was $1 \mathrm{~atm}$. The internal pressure of the meteorite over the long time span during its alteration was not constant. Although internal pressure cannot be measured directly, it can be inferred from the stress relations. When the meteorite was largely metallic in composition, it was under strain, chiefly because of the thermal stresses induced by the cyclic process of solar radiation during the day and of cooling at night. As the meteorite became largely altered and the metallic compounds were converted to oxides and hydroxides, the internal stresses were greatly decreased.

Having now estimated approximate coordinates of

\footnotetext{
${ }^{5} 1$ kilolangley $=1,000$ langleys. 1 langley $=1 \mathrm{~g} \mathrm{cal}\left(15^{\circ} \mathrm{C}\right) / \mathrm{cm}^{2}=4.1855$ joules $/ \mathrm{cm}^{2}$
}

the time, temperature, and pressure variables of the Wolf Creek meteorite during its earth history, an attempt is made here to evaluate the effect of these variables on the state of the meteorite. To do this we will calculate their effects on a model meteorite.

\section{BEHAVIOR OF A MODEL METEORITE BODY IN A DESERT REGION}

DISTRIBUTION OF TEMPERATURE AND THERMAL STRESS

The thermal regime of a meteorite partly embedded in the sediments of a desert and exposed to the heat of the sun can be assessed by comparing the meteorite to a model body of similar size, shape, and physical properties and similarly embedded.

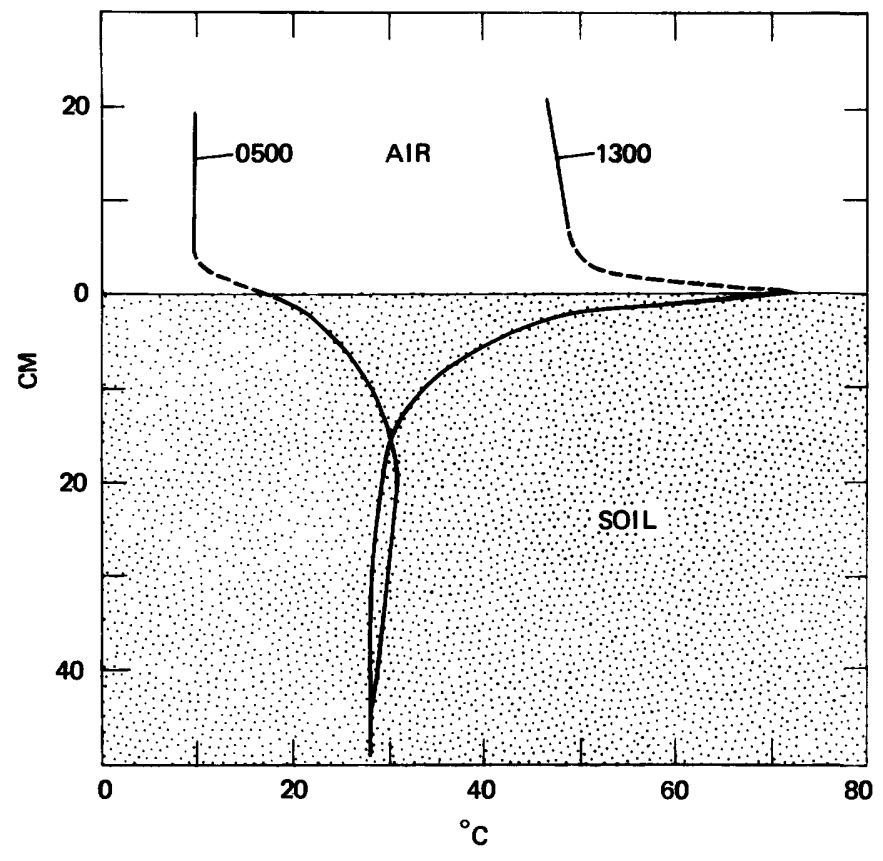

FIGURE 53.-Daily and nightly temperature extremes of the air above surface and of the soil in the desert floor at the Desert Laboratory, Carnegie Institution of Washington, near Tucson, Ariz., as measured by John G. Sinclair on June 21, 1955. Plot, reproduced by permission of author and publisher, by Roland Brinkmann, in Kayser (1967, p. 44).

Meteorite fragments are of various sizes and shapes, and it is only necessary to select two different masses and assume the shapes of a sphere, cylinder, and slab for purposes of calculation and comparison. A large mass weighing approximately $226.8 \mathrm{~kg}(500$ lb) ${ }^{6}$ was observed by Mason (1968) at Wolf Creek. To calculate the desired geometrical volume for a mass of this value, it is necessary to know its density. The nickel content of the Wolf Creek meteorite is 8.6 percent, and the average density of 360 iron-nickel meteorites having an average nickel content of 8.71 percent is $7.693 \mathrm{~g} / \mathrm{cm}^{3}$. Using this value of the density and the weight of $226.8 \mathrm{~kg}$, the dimensions of the sphere are volume $29,481 \mathrm{~cm}^{3}$ and radius $(a) 19.164$

${ }^{6}$ This weight represents an altered mass whose original weight would have been less than this value. It is merely selected as a convenient approximation for the weight of the model body. Larger masses may have been found and removed. 
cm. For other shapes having this same volume, the dimensions of a cylinder are radius $19.164 \mathrm{~cm}$, altitude $25.55 \mathrm{~cm}$; and for a slab are thickness $(2 a)$ $38.328 \mathrm{~cm}$, base $15.38 \times 50 \mathrm{~cm}$. An arbitrarily chosen mass $(2,268 \mathrm{~kg}), 10$ times the previous value, has a volume of $294,813 \mathrm{~cm}^{3}$. The dimensions are, for the sphere, radius $41.288 \mathrm{~cm}$; for the cylinder, radius $41.288 \mathrm{~cm}$, altitude $55.049 \mathrm{~cm}$; and for the slab, thickness $(2 a) 82.576 \mathrm{~cm}$, base $35.7 \times 100 \mathrm{~cm}$.

On the basis of the climatological data, previously presented, a temperature span of $0^{\circ} \mathrm{C}$ to $100^{\circ} \mathrm{C}$ was selected to bound the possible reaction coordinates. A search of various compilations of the pertinent physical properties shows that the most plentiful data are for the element iron, although there are some data for iron-nickel alloys. Few data for meteorites exist, but the coefficient of thermal expansion $(\alpha)$ of the meteorite from La Caille, Grasse, Alpes Maritimes, France, was measured by Fizeau (1869) and was found to be $11 \times 10^{-6}$ per ${ }^{\circ} \mathrm{C}$. In choosing the various constants for use in the calculations, values for iron were used, but the data for iron alloys containing nickel were considered in making the selections.

The thermal behavior of a spherical body while it is being heated from the outside was investigated by Williamson (1919), who derived the various equations for calculating the rate of heating of the sphere and for calculating the radial and tangential (circumferential) stresses developed as a result of heating. Assuming for a first approximation a constant rate of heating, Williamson (1919) observed that each element of the sphere experiences an expansion due to the temperature rise and a restoration of the equilibrium position by the induced internal stresses. The equations were extended by Williamson and Adams (1919), and their most recent form, together with extensive tables for facilitating the calculations, were given by Adams and Waxler (1960). For a sphere heated from the outside at a constant linear rate,

$$
\theta-\theta_{i}=h t-\frac{h}{6 \kappa}\left(a^{2}-x^{2}\right),
$$

n which

$\theta$ =temperature at a point $x / a$ from the center;

$\boldsymbol{\theta}_{i}=$ initial uniform temperature;

$h=$ rate at which the surface is heated, in ${ }^{\circ} \mathrm{C} / \mathrm{sec}$;

$t$ =time, in seconds;

$\kappa=$ thermal diffusivity;

$a$ =radius of the sphere;

$x=$ point inside the sphere; and

$\underline{x}=$ distance from the center of the sphere expressed

$a$ in terms of the radius.

The solution of this equation permits the determin- ation of the temperature at any point within the sphere.

To determine the radial stress:

$$
F_{\mathrm{r}}=\frac{\alpha h}{15 \kappa(e-f)}\left(a^{2}-x^{2}\right)
$$

To determine the tangential (or circumferential) stress:

$$
F_{t}=\frac{\alpha h}{15 \kappa(e-f)}\left(a^{2}-2 x^{2}\right)
$$

$\alpha=$ thermal linear coefficient of expansion.

$\left(\frac{1}{e}\right)=$ Young's modulus of elasticity $=E$.

$\left(\frac{f}{e}\right)=$ Poisson's ratio $=\sigma$.

$(e-f)=a$ parameter for the elastic effects.

The values used in the calculations, and their source, are:

$\alpha=11.71 \times 10^{-6}$ value for iron (Holborn and Day 1901).

$E=$ Young's modulus $=21.7 \times 10^{11}$ dynes $/ \mathrm{cm}^{2}$ (Zisman, 1933).

$\sigma=$ Poisson's ratio $=0.317$ (Zisman, 1933).

$K=$ Bulk modulus $=16.7 \times 10^{11}$ dynes $/ \mathrm{cm}^{2}$ (Zisman, 1933).

$G=$ Rigidity modulus $=8.38 \times 10^{11}$ dynes $/ \mathrm{cm}^{2}$

(Ide, 1936).

$\boldsymbol{\kappa}=$ thermal diffusivity $=0.181 \mathrm{~cm}^{2} / \mathrm{sec}$ (Ingersoll and others, 1948).

$(e-f)=0.0315 \times 10^{-11} \mathrm{~cm}^{2} /$ dyne based on $\sigma$ and $E$.

$(e-f)=0.0332 \times 10^{-11} \mathrm{~cm}^{2} /$ dyne based on $K$ and $G$.

Similar equations were also derived for the geometric forms of the slab and the cylinder.

in addition to the thermal constants for the model meteorite, we need the thermal constants for adobe soil. The thermal conductivity $(k)$ of adobe, calculated by the method of Smith (1942) and using data for adobe from Chang (1941) and other data from Ingersoll, Zobel, and Ingersoll (1954), was found to be $k=0.00066 \mathrm{cal} / \mathrm{cm} / \mathrm{sec} /{ }^{\circ} \mathrm{C}$. From this the value of the thermal diffussivity for adobe, $\kappa=0.002 \mathrm{~cm}^{2} / \mathrm{sec}$, was obtained. The consistency of the measured temperature data in Sinclair's (1922) table was checked by calculating the temperature at a depth of $2 \mathrm{~cm}$ in the adobe using the standard equations for periodic heat flow as given in Jakob and Hawkins (1942) and in Ingersoll, Zobel, and Ingersoll (1954) together with the value of $\boldsymbol{\kappa}$ for adobe given above and Sinclair's data for the temperature $0.4 \mathrm{~cm}$ below the ground surface. The results showed that for the measured maximum of $62.1^{\circ} \mathrm{C}$, the calculated value is $65.2^{\circ} \mathrm{C}$; and for the measured minimum of $22.0^{\circ} \mathrm{C}$, the calculated value is $23.2^{\circ} \mathrm{C}$. 
For the model meteorite body it is assumed (1) that a slab of metal lies buried to a depth, $a$ (equal to $1 / 2$ of its thickness $=2 a$ ), below the surface of the desert floor, (2) that the adobe floor and the model meteorite body are heated at a constant rate, and (3) that the quantity of solar heat striking both the desert adobe floor and the metal is the same.

With these assumptions it is now possible to evaluate the heating rate $h$ for the adobe floor and the metal by solving the Williamson and Adams (1919) equation for a slab for both the media and then by equating the resulting two values for $h$ as follows;

$$
\begin{gathered}
h=\frac{\theta-\theta_{i}}{t-\frac{\left(a^{2}-x^{2}\right)}{2 \kappa}} \\
\frac{\theta_{\text {adobe }}-\theta_{i}}{t-\frac{\left(a^{2}-x^{2}\right)}{2 \kappa}}=\frac{\theta_{\text {metal }}-\theta_{i}}{t-\frac{\left(a^{2}-x^{2}\right)}{2 \kappa}}
\end{gathered}
$$

Sinclair (1922) measured the temperatures in the adobe soil at a depth of $0.4 \mathrm{~cm}$ and found a minimum value of $\theta=17^{\circ} \mathrm{C}$ at 5:30 a.m. and a maximum value $\theta=71.5^{\circ} \mathrm{C}$ at $1: 00$ p.m. Substituting these data in the above equation, a maximum temperature of $115^{\circ} \mathrm{C}$ was calculated for the model meteorite body. In this calculation the modifications introduced by the boundary conditions of the metal have been neglected. The metal is surrounded by and underlain by adobe, and as these media have widely different conductivities and diffusivities, the adobe acts as an insulator, causing a higher overall temperature in the model meteorite body because it retains some of its heat for a longer time in the daily cycle. The magnitude of this effect was estimated by calculating the temperature in a slab of the metal at the contact of the metal and the adobe using the standard methods (Jakob and Hawkins, 1957). For a slab having a mass of $226.8 \mathrm{~kg}$ and a thickness of $38.328 \mathrm{~cm}$, the temperature at the ground surface is $114.6^{\circ} \mathrm{C}$ and at the contact is $113.8^{\circ} \mathrm{C}$. Similarly, for a slab having a mass of $2,268 \mathrm{~kg}$ and a thickness of $82.576 \mathrm{~cm}$, the temperature at the surface is $114.6^{\circ} \mathrm{C}$ and at the contact is $112.9^{\circ} \mathrm{C}$.

The temperature distribution in model meteorite bodies having the shape of a sphere, cylinder, and slab are given in table 10 for metallic masses of 226.8 $\mathrm{kg}$ and $2,268 \mathrm{~kg}$. These data are calculated for the upper half of the model. The calculated values are, of course, carried to more significant figures than are needed for this study, but they have been retained to permit checking.

A study of the data in table 10 shows that a tenfold increase in mass produces a corresponding $4 \frac{1 / 2}{\text {-fold }}$ temperature difference within each geometric shape. For the sphere the temperature difference changed from $1.2^{\circ} \mathrm{C}$ to $5.7^{\circ} \mathrm{C}$; for the cylinder it changed from $1.8^{\circ} \mathrm{C}$ to $8.5^{\circ} \mathrm{C}$; and for the slab it changed from $3.8^{\circ} \mathrm{C}$ to $17.0^{\circ} \mathrm{C}$. For very small fragments the temperature differences should be negligible. The shape of the body does significantly alter the temperature distribution within it. The temperature differences within a slab are approximately twice as great as those within the sphere and cylinder, and the cylinder is more divergent than the sphere.

The stresses within the heated bodies are taken following Williamson (1919) as $F_{\mathrm{a}}, F_{\mathrm{r}}$, and $F_{\mathrm{t}}$, which are, respectively, parallel to the axis and radially and tangentially in the plane at right angles to the axis. $X$ represents the displacement parallel to the axis of the element which was originally defined by the coordinates $(x, r)$, where $r$ is the radius. For a sphere the condition of equilibrium is given by:

$$
F_{\mathrm{t}}=F_{\mathrm{r}}+\frac{r}{2} \cdot\left(\frac{d F_{\mathrm{r}}}{d r}\right)
$$

which relates the tangential and radial stresses. Considering the second member on the right-hand side of the equation, it is apparent that at the center $(r=0)$ the tangential and the radial stress are equal and are positive in sign, and thus they represent tensional forces. The calculations show that the tangential stress (a tension) diminishes as $r$ increases, passes through the spherical shell of no strain, and becomes a compressive force.

For all of the geometric shapes chosen for the model, the bottom of the model is embedded in the soil well above the level at which no heat is received from solar radiation $(50-\mathrm{cm}$ depth in the normal soil profile). The sphere lies buried to a depth of its radius, $a$, and the cylinder lies with its altitude parallel to the desert floor and buried to a depth of its radius, $a$. For purposes of simplicity, the depression of this temperature level, under the meteorite, has been ignored. The position of the level of constant temperature would be depressed even further under the slab cited above.

The analysis of the thermal and stress behavior of a model meteorite body presented here is based on data which are reasonable estimates of conditions in the Wolf Creek desert. It yields a solution which is realistic.

$$
\text { STRESS CORROSION (CORROSION FATIGUE) }
$$

'Stress corrosion" is a term used by metallurgists to describe the simultaneous action of stress and corrosion in bringing about the mechanical failure of 
TABLE 10.-Calculated temperature and thermal stress in model meteorite bodies in the shape of a sphere, a cylinder, and a slab

$[\theta$ is the temperature at a distance $x$ from the center of a sphere of radius $a$, at a distance $x$ from center of a cylinder of radius $a$, and at a distance $x$ from the center of a slab whose thickness is $2 a$. See text for the dimensions of the various shapes having a given volume. A positive number indicates tension; a negative number, compression]

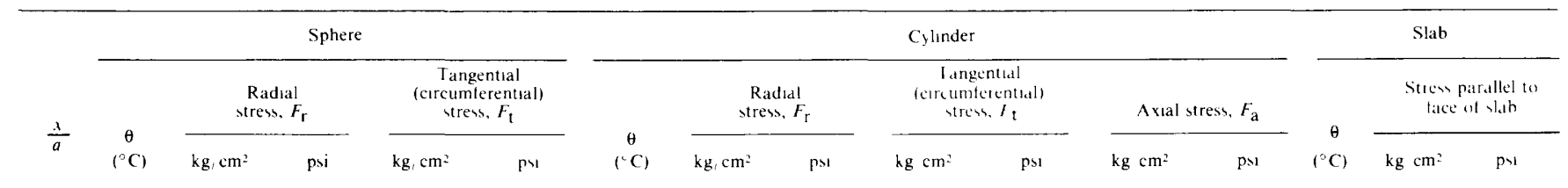

\begin{tabular}{|c|c|c|c|c|c|c|c|c|c|c|c|c|c|c|c|}
\hline \multicolumn{16}{|c|}{ Mass $226.8 \mathrm{~kg}(500 \mathrm{lb})$, volume $29,481 \mathrm{~cm}^{3}$} \\
\hline 0 & 113.4 & 15.93 & 226.58 & $15 . \overline{93}$ & 226.58 & 112.8 & 14.93 & 21236 & 1493 & 21236 & 2987 & 424.84 & 110.8 & 3982 & 556.38 \\
\hline .333 & 113.5 & 14.16 & 201.40 & 12.40 & 176.37 & 1130 & 13.27 & 18874 & 9.96 & 14167 & 2324 & 330.55 & 111.3 & 26.57 & 37792 \\
\hline .500 & 113.7 & 11.95 & 169.97 & 7.96 & 113.22 & 113.2 & 1120 & 15930 & 3.73 & 53.05 & 1493 & 21236 & 1111.9 & 9.96 & 14167 \\
\hline .667 & 113.9 & 8.84 & 125.73 & 1.76 & 25.03 & 1136 & 8.29 & 117.91 & -5.00 & -71.12 & 329 & $\begin{array}{r}46.79 \\
\end{array}$ & 112.6 & -13.33 & -18900 \\
\hline .800 & 114.2 & 5.73 & 8150 & -4.46 & -63.44 & 113.9 & 538 & 76.52 & -13.73 & -195.29 & -836 & -11891 & 113.3 & -36.63 & -521.00 \\
\hline 1.000 & 114.6 & 0 & 0 & -15.93 & -226.78 & 114.6 & 0 & 0 & -29.87 & -424.85 & -2987 & -424.85 & 114.6 & -79.64 & -1.132 .75 \\
\hline \multicolumn{16}{|c|}{ Mass $2,268 \mathrm{~kg}(5,000 \mathrm{lb})$, volume $294,813 \mathrm{~cm}^{3}$} \\
\hline 0 & 108.9 & 75.4 & $1,072.8$ & 75.4 & $1,072.8$ & 106.1 & 70.7 & 1.0057 & 70.7 & 1,0057 & 1386 & 1.9719 & 97.6 & 188.6 & 2.682 .1 \\
\hline .333 & 109.6 & 67.1 & 953.8 & 58.7 & 834.9 & 107.0 & 62.9 & 8942 & 47.2 & 671.2 & 107.9 & $1,534.6$ & 99.5 & 125.9 & 1.790 .0 \\
\hline 500 & 110.3 & 56.6 & 804.6 & 34.5 & 491.1 & 108.2 & 53.0 & 7543 & 17.7 & 2512 & 645 & 9026 & 101.8 & 47.1 & 669.9 \\
\hline 667 & 111.5 & 41.9 & 595.5 & 8.3 & $11 \times 2$ & 110.1 & 393 & 558.3 & -23.7 & -3365 & 153 & 217.3 & $105 i$ & $\begin{array}{r}4.1 \\
-63.1\end{array}$ & $\begin{array}{r}087.6 \\
-897.6\end{array}$ \\
\hline .800 & 112.6 & 27.2 & 386.2 & -21.1 & -300.4 & 111.7 & 25.5 & 3621 & -65.1 & $-925,2$ & -388 & -552.1 & 108.1 & -1735 & $-2,467.4$ \\
\hline 1000 & 114.6 & 0 & 0 & -75.4 & $-1,072.8$ & 114.6 & 0 & 0 & -1414 & $-2,011.4$ & -1386 & -1.9719 & 114.6 & -377.1 & $-5,3640$ \\
\hline
\end{tabular}

metals and alloys. Birchenall (1959) limited the term "stress corrosion" to those systems in which the stress is static and applied the term "corrosion fatigue" to those systems in which the stress is cyclic. In the previous section it was shown that the model meteorite body lying in the desert sand had developed a state of stress through cyclical processes. The surface layers of the body, during heating, contained residual stress and were in a state of compression, whereas the core, or the central portions, also containing residual stress, was in a state of tension. The cyclical repetition of the stressing conditions thus produced fatigue within the model meteorite bod:-

The tensile stresses developed in the iron geometric-shape bodies with a mass of $226.8 \mathrm{~kg}$, at the highest temperature reached by the bodies, ranged from 0 to $39.82 \mathrm{~kg} / \mathrm{cm}^{2}$, and the compressive stresses ranged from 0 to $-79.64 \mathrm{~kg} / \mathrm{cm}^{2}$. Similarly, in the mass 10 times heavier $(2,268 \mathrm{~kg})$, the tensile stresses ranged from 0 to $188.6 \mathrm{~kg} / \mathrm{cm}^{2}$, and the compressive stresses ranged from 0 to $-377.13 \mathrm{~kg} / \mathrm{cm}^{2}$. These tensile and the compressive stresses are considerably below the ultimate tensile and compressive strength of $3,500 \mathrm{~kg} / \mathrm{cm}^{2}$ for wrought iron and of $4,200 \mathrm{~kg} / \mathrm{cm}^{2}$ for structural steel, determined under static conditions on test pieces that are free of, or at least almost free of, existing stress. Thus, the model meteorite body never developed a sufficient stress to exceed its ultimate strength and rupture. Metallurgists have found, however, that metals subjected to the alternate application and removal of a stressing force become permanently stressed and develop a state of fatigue. Fatigued metals are cap- able of rupturing at stresses greatly below their ultimate strengths. The solids are weakened by such phenomena as embrittlement at grain boundaries and movements along slip and other structural planes. Any process which develops these surface defects leads to the development of cracks. Gensamer (1941, p. 26) stated "Ultimate failure in fatigue results from the propagation of a crack caused in the first place by repeated minute amounts of plastic deformation." The crack, once formed, spreads as the deforming cycles are repeated, and ultimately a large crack forms rapidly. According to Gensamer (1941, p. 26), "The crack nearly always follows such a direction as to be everywhere perpendicular to the greatest normal stress $\left(\sigma_{1}\right)$, both in the stage of slow development and during its final rapid propagation."

Fatigue tests on steels, under atmospheric conditions, show that the curve relating stress to the number of cycles to produce failure shows a knee in the curve at a value between 6 and 7 million cycles; a value of 10 million cycles is usually adopted (Woodward, 1948). After the initial crack forms, the limit fatigue stress falls by as much as 75 percent for high tensile alloy steels (Woodward, 1948). In a million years a model meteorite body lying in the desert would undergo 365 million cycles, so more than enough time would be available for stress failure.

After the first crack or cracks are formed, moisture can enter into the process, and the disintegration proceeds rapidly. Woodward (1948) stated that fresh water reduces the endurance limits of mild steels by 50 percent, and salt water, by 75 percent. The solutions cause pitting of the metal, and numerous 
cracks can radiate from the pitted surfaces and lead to failure.

The interpretation of the mechanisms by which stressed bodies disintegrate is based on thermodynamic considerations. Stressed phases are generally thermodynamically much less stable than their unstressed equivalents and are therefore more easily destroyed. The rate of the chemical reactions is controlled in part by the phase assemblages, by the temperature, and by those structures which give access to, or facilitate development of, surface area-such as cracks, cleavages, slip planes, and lamellae of dissimilar phases. These characteristics affect the rate of disintegration of both the model meteorite body and the real meteorite.

The model meteorite body is assumed to be a medium octahedrite, for which Mason (1962, p. 53-68) gave the following characterization: (1) The mineralogy consists chiefly of the iron-nickel alloys kamacite ( $\alpha$-iron, containing about 5.5 percent $\mathrm{Ni}$ ) and taenite $(\gamma$-iron, containing about 27-65 percent $\mathrm{Ni}$, with very small amounts of troilite, $\mathrm{FeS}$, schreibersite, $(\mathrm{Fe}, \mathrm{Ni})_{3} \mathrm{P}$, and (rarely) cohenite, $\mathrm{Fe}_{3} \mathrm{C}$, and daubreelite, $\mathrm{FeCr}_{2} \mathrm{~S}_{4}$; and (2) the texture and structures are dominated by the Widmanstätten lamellae, containing bands of kamacite 0.5 to $1.5 \mathrm{~mm}$ wide, that may conceal previous grain boundaries. Neumann lines arising from mechanical twinning and slip bands produced by small displacements along gliding planes may also be present. The Neumann lines within the bands of kamacite and the slip bands may have appeared under conditions of shock metamorphism resulting from impact.

Evidence on the manner of chemical attack on meteorites was given by Perry (1944), whose photomicrographs clearly show that limonite invades from the surface along twinning planes and attacks the kamacite. Most of the kamacite is replaced, until only the taenite lamellae remain. The taenite lamellae frequently outline the traces of the Widmanstätten pattern. If the taenite is replaced, it shows that significant amounts of nickel will be released in the last stage of the replacement process.

NATURAL PROCESS OF DISINTEGRATION COMPOSITION AND GEOCHEMICAL BALANCE

The exact phase assemblage of the meteorite from Wolf Creek crater, Australia, at the time of its impact with earth is not known. Taylor (1965) collected fragments of a medium octahedrite in the desert about 4 $\mathrm{km}$ southwest of the crater. Analysis of this meteorite showed 8.6 percent nickel and 0.4 percent cobalt. Well-developed Widmanstätten lamellae about 0.9 $\mathrm{mm}$ wide dominate the fragments. According to
Taylor (1965), these fragments may be part of the Wolf Creek meteorite. White, Henderson, and Mason (1967) observed pseudomorphic textures in the Wolf Creek meteorite which show that the newly formed lipscombite occurs as crusts lining the lath-shaped cavities of former schreibersite crystals and that jarosite occurs as "small crystals in cavities which probably held troilite" (p. 1195). The composition of the Wolf Creek meteorite at the time of impact can also be estimated from the present mineralogy. The present mineralogy of the Wolf Creek meteorite, the probable mineralogy of a medium octahedrite, the mineralogy of the desert sand, and the composition of rainwater from Australia (Carroll, 1962), are summarized in table 11 in the form of a geochemical balance relating the system before and after disintegration. From this we deduce that the Wolf Creek meteorite was composed principally of kamacite and taenite and that at least minor amounts of schreibersite and troilite were originally present. It also seems likely, from other studies, that if chromium was present in this meteorite, it would have been in chromite rather than daubreelite.

\section{STRESS RELATIONS RESULTING FROM IMPACI}

The theoretical behavior of a model meteorite body previously given and the descriptive mineralogy of the Wolf Creek meteorite presented in table 11 are bases for deducing the probable processes leading to the disintegration of the meteorite. The disintegration advanced in stages.

The first stage took place on impact. The meteorite was intensely shocked and was in large part fragmented by its impact with the earth. Heymann, Lipschutz, Nielsen, and Anders (1966, p. 622) described the thermal and pressure history of a typical fragment formed by the breakup of a meteoroid on impact as follows:

A typical fragment must have passed through the following stages during impact. First, it was heated and compressed by the shock wave. Its temperature at this point was equal to the sum of an "adiabatic" and a "residual" term and depended strictly on the shock intensity. A fraction of a millisecond later the rarefaction wave decompressed it and cooled it to the residual temperature and threw it clear of the explosion area. From then on the fragment cooled by radiation and conduction. Its cooling time therefore depended on its size and ejection velocity and might be expected to range from a few seconds to a few minutes.

These investigators studied a collection of meteorite fragments from the rim of the Canyon Diablo crater and found that 72 percent of the fragments were strongly shocked at pressures $\geqslant 750$ kilobars and that 28 percent were moderately shocked at pressures of 130-750 kilobars. Temperatures in the fragments were estimated to have been $\geqslant 760^{\circ} \mathrm{C}$. Similar con- 
TABLE|11.-Distribution of the elements in the disintegration products of the Wolf Creek meteorite and in the source materialsa study of geochemical balance

[Data for Wolf Creek meteorite (except for pecoraite) from White, Henderson, and Mason (1967); data for medium octahedrite from Mason $(1962$, p. 62). M, major; n.d., not detected; vm, very minor; $m$, minor. Values for disintegration products are in weight percent of oxide formed with element listed in col. 1; values for source materials, in weight percent of element]

\begin{tabular}{|c|c|c|c|c|c|c|c|c|c|c|c|c|c|c|c|c|c|c|c|}
\hline \multirow{4}{*}{ Element } & \multicolumn{9}{|c|}{ Disintegration products } & \multicolumn{10}{|c|}{ Source materials } \\
\hline & \multicolumn{9}{|c|}{ Wolf Creek meteorite } & \multicolumn{6}{|c|}{ Typical medium octahedrite } & \multirow{2}{*}{\multicolumn{3}{|c|}{ Sand }} & \multirow{3}{*}{ Rainwater } \\
\hline & \multicolumn{2}{|c|}{$\begin{array}{c}\text { Principal } \\
\text { phases }\end{array}$} & \multicolumn{7}{|c|}{ Minor phases } & \multicolumn{2}{|c|}{$\begin{array}{c}\text { Principal } \\
\text { phases }\end{array}$} & \multicolumn{4}{|c|}{ Minor phases } & & & & \\
\hline & 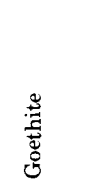 & 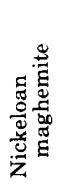 & 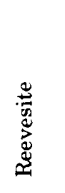 & 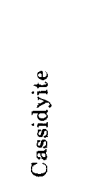 &  & 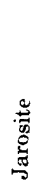 & 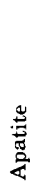 & \% & 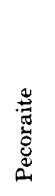 & 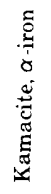 & 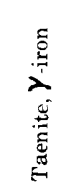 & 总 & 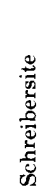 & $\begin{array}{l}\stackrel{\Xi}{0} \\
\frac{\pi}{8} \\
8\end{array}$ & 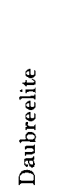 & 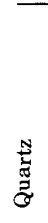 & 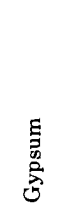 & 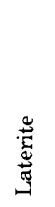 & \\
\hline $\mathrm{Fe}$ & M & $\mathbf{M}$ & ${ }^{1} 18.1$ & n.d. & $\mathbf{M}$ & M & $\ldots$ & $\ldots$ & 20.7 & $\mathbf{M}$ & M & $\mathbf{M}$ & $\mathbf{M}$ & $\mathbf{M}$ & $\mathbf{M}$ & $\ldots$ & $\ldots$ & $\mathbf{M}$ & $\ldots$ \\
\hline $\mathrm{Ni}$ & $0.7-1.3$ & $\leq 8.7$ & 52.1 & $6.4-16.2$ & 0.9 & 19. & - & $\ldots$ & 51.5 & 5.5 & $27-65$ & $\ldots$ & $\mathbf{M}$ & $\ldots$ & $\ldots$ & $\ldots$ & $\ldots$ & -.. & $\ldots$ \\
\hline Co & $\leq 0.3$ & $\leq .6$ & $\leq .2$ & $\leq .4$ & $\leq .1$ & $\ldots$ & $\ldots$ & $\ldots$ & $\ldots$ & $\mathrm{vm}$ & vm & $\ldots$ & $\ldots$ & .-- & $\cdots$ & $\ldots$ & -- & $\ldots$ & $\ldots$ \\
\hline P &.-- & $-\cdots$ & $\cdots$ & 39.2 & $\mathbf{M}$ & $\ldots$ & $\mathbf{M}$ & $\ldots$ & $\ldots$ & ... & ... & $\ldots$ & $\mathbf{M}$ & $\ldots$ & $\ldots$ & $\ldots$ & $\ldots$ & $\ldots$ & $\cdots$ \\
\hline S & $\ldots$ & --. & $\ldots$ & ... & ... & $\mathrm{M}$ & $\ldots$ & $\ldots$ & $\ldots$ & ... & ... & $\mathbf{M}$ & $\ldots$ & ... & $\mathbf{M}$ & ... & M & $\ldots$ & $\ldots$ \\
\hline $\mathrm{Mg}$ & $\ldots$ & $\ldots$ & n.d. & $2.2-5.7$ & $\leq .1$ & In & $\ldots$ & $\ldots$ & .5 & $\ldots$ & -- & $\ldots$ & $\ldots$ & $\ldots$ & $\ldots$ & $\ldots$ & - & -.. & ${ }^{3} \mathrm{~m}$ \\
\hline $\mathrm{Ca}$ & -- & $\ldots$ & $\ldots$ & 32.3 & $-\ldots$ & $\ldots$ & M & ..- & $\ldots$ & ... & $\ldots$ & $\ldots$ & ... & $\ldots$ & ... & ... & $\mathbf{M}$ & $\ldots$ & ${ }^{4} \mathrm{~m}$ \\
\hline $\mathrm{Si}---1$ & $\ldots$ & $\ldots$ & $\ldots$ & .... & $\ldots$ & $\ldots$ & $\ldots$ & $\overline{\mathrm{M}}$ & 310 & $\ldots$ & $\ldots$ & $\ldots$ & $\ldots$ & ..- & $\ldots$ & $\mathbf{M}$ & $\ldots$ & $\ldots$ & $\ldots$ \\
\hline $\mathrm{C}$ & $\ldots$ & ... & ${ }^{\dagger} \mathbf{M}$ & $\ldots$ & ... & ... & ... & $\ldots$ & ... & ... & ... & $\ldots$ & -.- & ${ }^{6} \mathrm{M}$ & $\ldots$ & $\ldots$ & ... & $\ldots$ & ${ }^{7} \mathrm{~m}$ \\
\hline $\mathrm{H}_{2} \mathrm{O} \ldots$ & $\mathbf{M}$ & ... & $M$ & $\ldots$ & $\ldots$ & $\mathrm{M}$ & $\mathrm{M}$ & $\mathrm{M}$ & 9.7 & $\ldots$ & ... & $\ldots$ & $\ldots$ & $\ldots$ & -.. & $\ldots$ & M & M & $\mathbf{M}$ \\
\hline $\mathrm{Na}$ & $\ldots$ & $\ldots$ & $\ldots$ & ... & $\ldots$ & $\mathrm{M}$ & $\ldots$ & $\ldots$ & $\ldots$. & $\ldots$ & $\ldots$ & $\ldots$ & ... & ... & $\ldots$ & $\ldots$ & $\ldots$ & $\ldots$ & ${ }^{\prime} \mathrm{m}$ \\
\hline $\mathrm{Al}$ & $\ldots$ & $\ldots$ & $\ldots$ & $\ldots$ & $\ldots$ & IM & ... & $\ldots$ & 1.4 & $\ldots$ & $\ldots$ & $\ldots$ & $\ldots$ & $\ldots$ & $\ldots$ & $\ldots$ &.-- & $\mathbf{M}$ & $\ldots$ \\
\hline $\mathrm{Cr}$ & $\cdots$ & $\cdots$ & $\cdots$ & $\cdots$ & $\ldots$ & $\cdots$ & $\cdots$ & $\ldots$ & $\begin{array}{l}1.4 \\
-.-\end{array}$ & $\ldots$ & $\cdots$ & $\ldots$ & $\ldots$ & $\cdots$ & $\mathbf{M}$ & $\cdots$ & -- & $\ldots$ & $\cdots$ \\
\hline $\begin{array}{l}{ }^{1} \mathrm{Fe}_{2} \mathrm{O}_{3} . \\
{ }^{2} \mathrm{FeO} .\end{array}$ & & & & $\begin{array}{l}{ }^{4} \mathrm{MgCl}_{2} \\
{ }^{4} \mathrm{CaCl}_{2} .\end{array}$ & & & & & ${ }^{5}(\mathrm{C}$ & & & & & & $\begin{array}{l}\mathrm{O}_{2} \cdot \\
\mathrm{aCl} .\end{array}$ & & & & \\
\hline
\end{tabular}

ditions must have prevailed at the Wolf Creek crater. Under these conditions of pressure and temperature, all macroscopic and microscopic cracks would have been healed.

\section{PHYSICAL AND CHEMICAL CHARACTERISTICS AND RELATIONSHIPS}

The second stage in the disintegration was probably the longest in duration. It consisted chiefly of the mechanical cracking of the meteorite. As White, Henderson, and Mason (1967) observed, the meteorite is remarkably preserved as a pseudomorph, even though it contains a system of cracks. They noted (p. 1196) only a minimal amount of "flaking-off of successive layers of oxide ***" and attributed this coherence to the absence of frost in the region; this certainly was an important factor. The coherence of the phases into a single unit was also determined by the manner of crack development. Thermal stressing caused cracks to extend from the interior of the meteorite to the surface and permitted reactions to take place throughout the fragment. A purely surface attack would have caused reaction rinds, and the spalling of the rind would easily follow such a process. The crack development in one slice of the meteorite is shown in figure 54. It consists of several systems of cracks; one major system of sub- parallel cracks is nearly parallel to the scale in the photograph.

McCall (1965, p. 978-991) described the surface morphology of the weathered meteorite fragments and called the fragments iron shale balls. These fragments have a breadcrusted surface suggestive of volcanic bombs and a tail that McCall suggested has the form "of molten drops separated from a larger molten mass in flight."

With these observations as a guide and the knowledge of the model meteorite theory as developed in this report, one can deduce the probable manner in which the second stage progressed. The fragments of the meteorite were stressed at the time of impact (Heymann and others, 1966) and were still in a state of stress when alteration began. The thermal stress was added during a daily heating and cooling cycle. Calculations show that during the heating cycle, the fragments were in a state of tension from the center to the thin zone of no strain, but were in a state of compression from the thin zone of no strain to the outer surface. During the cooling cycle, the mechanical state of the fragments reversed, and the outer shells were in a state of tension while the part from the thin zone of no strain to the center was in a state of compression. The alternating cycle of heating and cooling with its thermal stressing-al- 


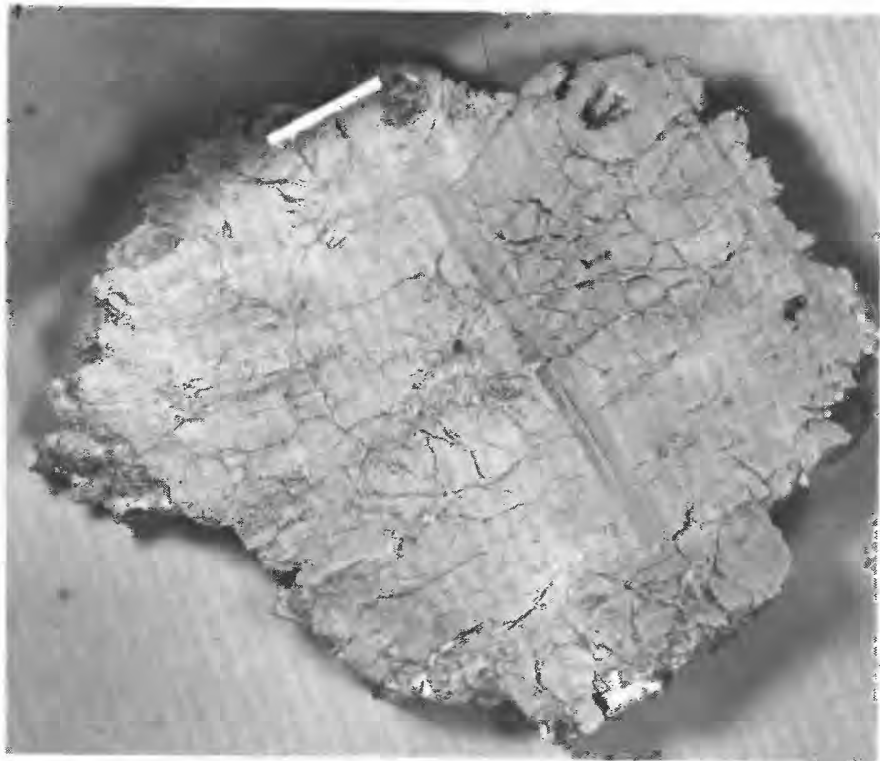

Figure 54.-Crack development in the Wolf Creek meteorite. Subparallel system parallels the 6 -inch white scale.

ternating between tension and compression-was repeated every day. The magnitude of these effects varied slightly with the seasons and was interrupted by occasional torrential rains. Repeated application of these stressing forces ultimately induced a state of fatigue in the metal phases which in turn led to crack formation. Movement along Widmanstätten band boundaries and Neumann lines also produced some cracks. Ultimately the fragments cracked from fatigue alone. When the cracks had widened enough to permit the entrance of water, mechanical disintegration advanced rapidly, and chemical reaction also occurred. The water films helped to widen the cracks, because they opposed the compressive forces attendant upon cooling. The water films were trapped in the cracks of the meteorite at night. During the morning heating cycle, the water films behaved as tiny hydrothermal bombs until expansion permitted some of the water to escape by leaking.

Rainwater entering the cracks set off chemical reactions in this system, and as a result of these reactions, the system underwent physical changes. The cracks were produced slowly and eventually extended to the center and then to the bottom. They were the principal paths along which the films of rainwater moved. The chemical system, so formed, consisted chiefly of taenite, kamacite, and water containing dissolved air and behaved as a collection of tiny electrochemical cells. During the disintegration of the meteorite, some important volume change must have occurred, for the molar volumes of the reactants iron, nickel, and water are 7.09, 6.59, and
$18.009 \mathrm{~cm}^{3}$, respectively, whereas the molar volumes of the principal products, goethite and maghemite, are 20.82 and $43.44 \mathrm{~cm}^{3}$. A determination (by Fahey) of the water content of selected fragments representative of the meteorite, gave 1.12 percent water lost when heated below $110^{\circ} \mathrm{C}$ and 9.28 percent water lost above $110^{\circ} \mathrm{C}$. As goethite loses 10.14 percent water above $110^{\circ} \mathrm{C}$, these data suggest that the Wolf Creek meteorite is chiefly goethite. A specific-gravity determination on several fragments of the meteorite yielded the value of 3.98 , and this supports the conclusion that the Wolf Creek meteorite studied by us is chiefly goethite. If one assumes that the Wolf Creek meteorite had a specific gravity of 7.69 before disintegration and uses the value of 3.98 for the present specific gravity of the meteorite, an increase of volume of just under 50 percent is indicated. As the reactions took place very slowly, over long periods of time, the volume-expansion process due to oxidation did not rupture or fracture the meteorite into myriads of small fragments.

The assemblage of phases, which formed the reactants, was dominantly kamacite and taenite and very subordinately troilite (FeS) and schreibersite $(\mathrm{Fe}, \mathrm{Ni})_{3} \mathrm{P}$. These may, for simplification, be referred to the system $\mathrm{Fe}-\mathrm{Ni}-\mathrm{H}_{2} \mathrm{O}-\mathrm{O}_{2}$ at temperatures from $25^{\circ} \mathrm{C}$ to $100^{\circ} \mathrm{C}$. The system was elastically stressed, and accordingly the strained phases were even less stable thermodynamically than their unstrained equivalents. Phase relations for this system at these temperatures are incomplete, and $\mathrm{Eh}-\mathrm{pH}$ diagrams containing both nickeloan maghemite and goethite are not available. Although the complete Eh-pH diagrams do not exist, sufficient data are available to indicate the probable physicochemical environment and the course of the reactions.

To interpret the course of the reactions at this early stage in the disintegration of the meteorite, the geochemical balance (table 11) may be examined further. The principal solid phases, the reactants, are the two alloys of iron and nickel, kamacite (nickel-poor) and taenite (nickel-rich). The relative stability of these two metallic phases can be observed directly in polished surfaces of altered meteorites where the relict taenite lamellae are encased by goethite (Perry, 1944). The oxidation and hydration of the kamacite to form goethite proceeds along the planes of Widmanstätten patterns, along grain boundaries, and probably along the Neumann lines. The liquid phase and its vapor which accomplished this disintegration was rainwater which contained some dissolved oxygen absorbed from the air. This dissolved gas was active in the reaction forming goethite and maghemite. Coker (1954) gave the solubility of air in water as follows: $14.6 \mathrm{ppm}$ (parts per million) at $0^{\circ} \mathrm{C}$, 
$10.1 \mathrm{ppm}$ at $15^{\circ} \mathrm{C}$, and $7.5 \mathrm{ppm}$ at $30^{\circ} \mathrm{C}$. Rainwaters from various localities, taken under a wide variety of conditions, have a $\mathrm{pH}$ range of 4 to 6 and a corresponding Eh range of +0.55 to +0.45 volts, and they are accordingly oxidizing in character (Baas-Becking and others, 1960). Carroll (1962) summarized data for rainwaters in Australia, and from these data we assume that the $\mathrm{pH}$ of the rainwater was approximately 6.0.

The electrochemical reaction of metals in contact with distilled water and with salt water of various concentrations has been studied by Whitmore (1933), who found that a slab of iron immersed in distilled water at $25^{\circ} \mathrm{C}$ produced an environment that became more alkaline with time. Thus at the end of 25 hours, the system iron-distilled water had a pH of 6.7(practically identical with that of the blank solution), but after 400 hours its $\mathrm{pH}$ had risen to 7.5. Nickel reacted more quickly, having a solution with a $\mathrm{pH}$ of $7.1_{\text {a }}$ after 24 hours and 7.3 after 400 hours. Whitmore (1933) showed that steel slabs immersed in salt water with free access to oxygen of the air form brown ferric hydroxide, whereas steel slabs coated with pyroxylin primer to exclude the air form green ferrous hydroxide under the coating. He measured the $\mathrm{pH}$ of a saturated solution of ferric hydroxide to be 7.0 and of ferrous hydroxide to be 9.5 . These experiments suggest that the formation of the hydroxide controls the $\mathrm{pH}$. A similar increase in $\mathrm{pH}$ to about 7.0 probably took place when the rainwater moved down the cracks and into the meteorite.

Examination of the Eh-pH diagrams in Garrels and Christ (1965) for the iron and nickel systems at $25^{\circ} \mathrm{C}$ shows that, at the Eh-pH conditions of rainwater, the metals iron and nickel are completely unstable with respect to hematite, $\mathrm{Fe}_{2} \mathrm{O}_{3}, \mathrm{Fe}(\mathrm{OH})_{3}$, and the nickel ion in solution ( $\left.\mathrm{Ni}^{\mathrm{i}+2} \mathrm{aq}\right)$, 'and that these metals could form such compounds or ions in solution. The stability field of magnetite on their diagrams excludes this phase as a possible member of the natural assemblage. Stability fields for goethite and maghemite are not given. Langmuir (1969) gave the free-energy data for maghemite and, on the basis of the activity product $K=\left(\alpha \mathrm{Fe}^{+3}\right)\left(\alpha\left(\mathrm{OH}^{-}\right)\right)^{3}$, suggested that maghemite is less stable than goethite at $25^{\circ}$ C. John L. Haas, Jr. (written commun., 1970, stated that nickeloan maghemite is as stable as goethite. The constant alternating elastic stress in the natural system may tend to form metastable phases.

The abundance of goethite in the Wolf Creek meteorite as the chief reaction product suggests that the system was entirely oxidizing in character. This reaction forming goethite released nickel, and since the alloy kamacite may contain as much as 5.5 percent nickel, the nickel must be accounted for in the replacement products. The microprobe analyses show that the goethite contains only 0.7 to 1.30 percent $\mathrm{NiO}$ ( 0.55 to 1.02 percent $\mathrm{Ni}$ ). The second most abundant product of the reaction is the phase nickeloan maghemite, which is shown by microprobe analysis to contain as much as 8.7 percent $\mathrm{NiO}(6.84$ percent Ni).

Probable reactions to produce goethite, or its polymorph, lepidocrocite, and maghemite were given by Doyle (1968). In his experimental study he investigated the reaction

$$
4 \mathrm{Fe}^{+2}+\mathrm{O}_{2}+6 \mathrm{H}_{2} \mathrm{O}^{\prime} \longrightarrow 4 \mathrm{FeO} \cdot \mathrm{OH}^{+}-8 \mathrm{H}+4 \mathrm{E}^{-} \text {, }
$$

and he found that under his experimental conditions it was almost impossible to prevent the oxidation of some of the ferrous iron to ferric iron because maghemite formed with the goethite. This is a close parallel to the assemblage in the Wolf Creek meteorite.

Coker (1954) found the solubility of oxygen from the atmosphere to be $15 \mathrm{ppm}$ in rainwater. Using this value and the above equation, 213 liters of rainwater are required to furnish the oxygen necessary to convert 1 gram of pure iron to goethite. Obviously other sources of oxygen are available, such as the air which enters the cracks and oxygen liberated in the catalytic decomposition of water in the hydrothermal system. The reaction given above would probably occur more rapidly during the heating cycle and the early part of the cooling cycle.

It is desirable to evaluate the probable reaction time necessary to convert the iron-nickel alloys to goethite and nickeloan maghemite, and fortunately such experimental data are available so a comparison can be made. The rate at which iron and iron alloys corrode has been studied extensively by electrochemists. In thoroughly dry atmospheres, iron may not be detectably corroded; in moist atmospheres, higher nickel contents of the alloy cause greater stability. This is in accord with the alteration of meteorites where the greater stability of taenite over kamacite is abundantly demonstrated and easily observed as in the photomicrographs of Perry (1944). Iron and steel sheets, under no stress and not cracked but exposed to the earth's atmosphere, corrode at the rate of 6 to 40 milligrams per square decimeter per day. Expressed in other units, this rate of corrosion is about 0.0028 to 0.0188 centimeters per year, or 2.8 to 18.8 centimeters per thousand years (McKay and Worthington, 1936, p. 243). In time, even the nickel-rich alloys corrode, just as their natural equivalent, taenite, does. These time data for the rate of corrosion on test slabs are a realistic estimate for the probable rate of disintegration of the Wolf Creek meteorite. 
SUGGESTED PATH OF THE OXIDATION PROCESS

John L. Haas, Jr., U.S. Geological Survey, examined our data and suggested a pattern for the oxidation of kamacite (nickel-poor alloy) and taenite (nickel-rich alloy) based on thermodynamic considerations. He kindly allowed us to use his notes and calculations (Haas, written commun., June 19, 1970), and they are summarized herewith.

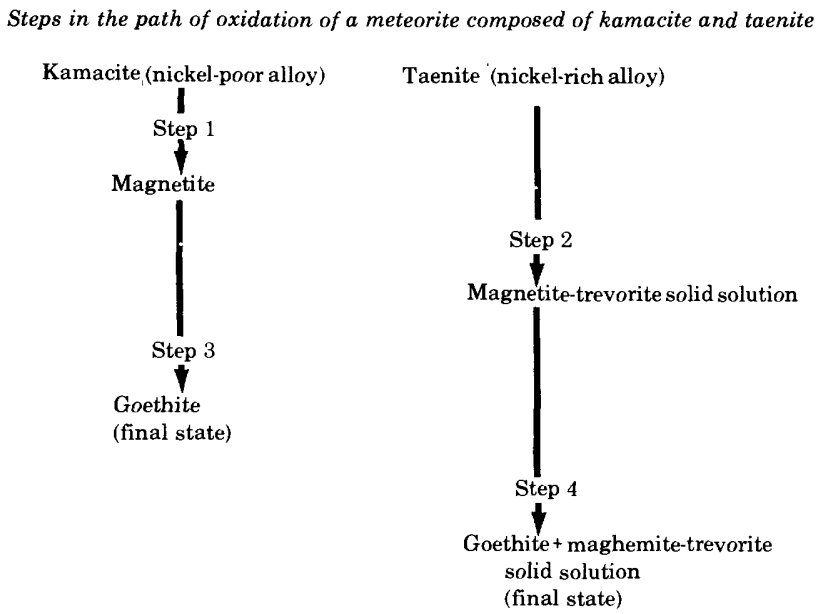

Thus, the final state of these reactions is goethite and goethite+maghemite-trevorite solid solution.

The thermochemical data used in the following calculations and given below are taken from Langmuir (1969), except for $\mathrm{NiFe}_{2} \mathrm{O}_{4}$ and $\mathrm{Ni}^{+2}$, which are taken from Wagman and others (1969).

\begin{tabular}{|c|c|}
\hline Species & $\Delta F($ kcal mole $)$ \\
\hline Trevorite, $\mathrm{NiFe}_{2} \mathrm{O}_{4}$ & -232.6 \\
\hline Magnetite, $\mathrm{FeFeO}_{4}$, & -243.09 \\
\hline Maghemite $\left(\Im 1 / 3 \mathrm{Fe}_{2 / 3}\right) \mathrm{Fe}_{2} \mathrm{O}_{4}$ & -226.35 (adjusted to agree with defect formula) \\
\hline Goethite, $\mathrm{FeO} \cdot \mathrm{OH}$ & -116.375 \\
\hline $\mathrm{Fe}^{+2}$ & -21.80 \\
\hline $\mathrm{Fe}^{+3}$ & -4.02 \\
\hline $\mathrm{Ni}+{ }^{2}$ & -10.9 \\
\hline $\mathrm{H}_{2} \mathrm{O}(\mathrm{l})$ & -56.688 \\
\hline
\end{tabular}

The maghemite in the meteorite contains as much as 8.7 percent $\mathrm{NiO}$ (6.8 percent $\mathrm{Ni})$. The formula weight of trevorite is $234.41 \mathrm{~g} / \mathrm{mole}$, and that of maghemite is $212.93 \mathrm{~g} / \mathrm{mole}$. A ratio of $1: 3$ of trevorite to maghemite contains 6.8 percent of nickel, and this corresponds to the amount of nickel in the nickel-rich alloy, taenite, in the meteorite. This ratio, which was obtained from both the maghemite-trevorite solid solution and the taenite, will be used when the ratios of end members are considered in further calculations. The abbreviation ss refers to the solid solution between trevorite and maghemite which has been observed, and the abbreviation ss' refers to the solid solution between trevorite and magnetite which is theoretically possible. The solid solutions are assumed to be ideal-that is, the activity of the end members $a_{i}$ is equal to the mole fraction $N_{i}$
Reaction involved in step 1, kamacite $\rightarrow$ magnetite.-Kamacite is irreversibly oxidized to magnetite. Because of its nickel content, taenite is not reactive relative to kamacite and undergoes no alteration at this point. First, water in contact with the kamacite spontaneously attacks the kamacite, producing magnetite and hydrogen gas. The hydrogen gas diffuses out of the meteorite body. No oxygen is needed, though any supplied increases the rate of reaction. The rate of the irreversible reaction also increases in the presence of carbonates, sulfates, and phosphates which are in the water as the result of solubility in rainwater or oxidation occurring in the outer parts of the body. Increase in the temperature to $100^{\circ} \mathrm{C}$ plus hastens the deterioration even more.

Reaction involved in step/2, taenite $\rightarrow$ magnetitetrevorite solid solution $\left(s^{\prime}\right)$.-After the immediately available kamacite has been oxidized to magnetite, the water and its dissolved salts begin to attack the taenite. The product will be a solid solution between trevorite and magnetite which is controlled by the ratio of nickel to iron in the taenite and by the distribution coefficient of nickel between the water and the oxide solid solution. Here it is assumed that there is no partitioning of the nickel in to the aqueous phase and depleting of the solid solution below that which would be expected from simple oxidation of taenite and that which is actually observed in the trevoritemaghemite (ss). This reaction is irreversible, and all the attributes which accompany the oxidation of iron-rich kamacite also apply to the oxidation of taenite to $\mathrm{ss}^{\prime}$.

At this level of oxidation, the $\mathrm{Ni}^{+2}$ and $\mathrm{Fe}^{+2}$-and$\mathrm{Fe}^{+3}$ concentrations in solution can be calculated. Consider the reaction of solid solution $\mathrm{ss}^{\prime}$ with $\mathrm{H}_{2} \mathrm{O}$ (l) in the proximity of metal and thus in the presence of about 1 atmosphere $\mathrm{H}_{2}$ pressure. Ionic-strength effects are neglected.

$$
\mathrm{FeFe}_{2} \mathrm{O}_{4}\left(\mathrm{ss}^{\prime}\right)+6 \mathrm{H}^{+}+\mathrm{H}_{21}=3 \mathrm{Fe}^{+2}+4 \mathrm{H}_{2} \mathrm{O}
$$

For this reaction.

$$
\begin{aligned}
\log K=35.96= & 3 \log \left[\mathrm{Fe}^{+2}\right]-\log \left[\mathrm{FeFe}_{2} \mathrm{O}_{4}\left(\mathrm{ss}^{\prime}\right)\right] \\
& +6 \mathrm{pH}-\log P\left(\mathrm{H}_{2}\right)
\end{aligned}
$$

Whitmore (1933) measured the pH of solutions in contact with weathering nickel-iron alloys and obtained a mean value of 7.0. Using this value and 0.75 for $\left[\mathrm{FeFe}_{2} \mathrm{O}_{4}^{\prime}\left(\mathrm{ss}^{\prime}\right)\right]$,

$$
\begin{aligned}
\log \left[\mathrm{Fe}^{+2}\right] & =-2.052 \\
{\left[\mathrm{Fe}^{+2}\right] } & =0.0089 \mathrm{molal}
\end{aligned}
$$

Under these conditions there will be no $\mathrm{Fe}^{+3}$ in the solution, so $\left[\mathrm{Fe}^{+3}\right]=0$ (for all practical purposes).

Next, consider the solution of the trevorite component: 
$\mathrm{NiFe}_{2} \mathrm{O}_{4}\left(\mathrm{ss}^{\prime}\right)+6 \mathrm{H}^{+}+\mathrm{H}_{2}=\mathrm{Ni}^{+2}+2 \mathrm{Fe}^{+2}+4 \mathrm{H}_{2} \mathrm{O}$

subject to the following conditions:

$\mathrm{H}_{2} \simeq 1 \mathrm{~atm}$

$\mathrm{pH}=7$

$\left[\mathrm{NiFe}_{2} \mathrm{O}_{4}\left(\mathrm{ss}^{\prime}\right)\right]=0.25$

$\left[\mathrm{Fe}^{+2}\right]=0.0089$ molal

For this reaction

$\log K=35.67=\log \left[\mathrm{Ni}^{+2}\right]+2 \log \left[\mathrm{Fe}^{+2}\right]$

$-\log \left[\mathrm{NiFe}_{2} \mathrm{O}_{4}\left(\mathrm{ss}^{\prime}\right)\right]+6 \mathrm{pH}-\log P\left(\mathrm{H}_{2}\right)$

The following concentrations can be calculated:

$\log \left[\mathrm{Ni}^{+2}\right]=-12.828,\left[\mathrm{Ni}^{+2}\right]=0.0015 \mathrm{molal}$

$\left[\mathrm{Ni}^{+2}\right] /\left(\left[\mathrm{Fe}^{+2}\right]+\left[\mathrm{Fe}^{+3}\right]\right)=0.17$

At this level of oxidation the assemblage is:

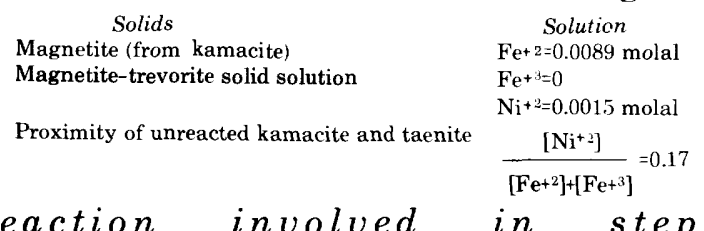

Reaction involved in step 3, magnetite - goethite-Only long after the oxidation front caused by the spontaneous reaction of $\mathrm{H}_{2} \mathrm{O}$ with metal has passed a given point in the meteorite does the site begin to see the effect of atmospheric oxygen. After the spinels form, the dissolved oxygen is the only oxidant.which causes further oxidation. Goethite is produced in proportion to the rate at which oxygen is provided.

The concentration of $\mathrm{Ni}^{+2}$ and $\left(\mathrm{Fe}^{+2}+\mathrm{Fe}^{+3}\right)$ in solution at the magnetite?-goethite boundary can be calculated. The term "magnetite?" is used because there is some question as to what spinel is stable at the boundary. Although it is a solid solution with trevorite in the 1:3 ratio, there is a question whether the defect structure is applicable at this point. In the pure $\mathrm{Fe}-\mathrm{O}$ system at $25^{\circ} \mathrm{C}$, there is no appreciable defect in the magnetite at the magnetite-hematite or magnetite-goethite boundary. It is assumed here that there is no defect at the "spinel"-hematite boundary" where the spinel is in the system $\mathrm{NiFe}_{2} \mathrm{O}_{4}-\mathrm{FeFe}_{2} \mathrm{O}_{4}$ $\left(\square \frac{1 / 3}{F_{2} e_{2 / 3}}\right) \mathrm{Fe}_{2} \mathrm{O}_{4}$, which is to say that the spinel lies on the magnetite-trevorite boundary, and there is no significant maghemite molecule in the solid solution. This is most probable because a large excess of nearly pure magnetite is present which was produced from the oxidation of kamacite. If the spinel is assumed to be free of defects, the fugacity of oxygen at the spinelgoethite boundary is calculated as follows:

$$
2 \mathrm{FeFe}_{2} \mathrm{O}_{4}\left(\mathrm{ss}^{\prime}\right)+3 \mathrm{H}_{2} \mathrm{O}+1 / 2 \mathrm{O}_{2}=6 \mathrm{FeOOH}
$$

For this reaction $\log K=30.8$.

To calculate the fugacity $(f)$ of oxygen, we have for $N\left(\mathrm{FeFe}_{2} \mathrm{O}_{4}\right)=0.75$ the following:

$$
\log K=30.8=-2 \log \mathrm{FeFe}_{2} \mathrm{O}_{4}-1 / 2 \log \mathrm{O}_{2},
$$

from which $\log \mathrm{O}_{2}=-61.1$, and $f_{\mathrm{O}_{2}}=10^{-61.1} \mathrm{~atm}$.
From the $\mathrm{H}_{2} \mathrm{O}-\mathrm{O}_{2}-\mathrm{H}_{2}$ equilibria,

$$
\log \mathrm{H}_{2}=\frac{\left(-83.1-\log \mathrm{O}_{2}\right)}{2}
$$

and thus $\log \mathrm{H}_{2}=-11.0$. From these data it is possible to calculate as before

$$
\begin{aligned}
& \mathrm{Fe}^{+2}=0.0000019 \text { molal } \\
& \mathrm{Ni}^{+2}=0.00000032 \text { molal } \\
& \left(\mathrm{Ni}^{+2} / \mathrm{Fe}^{+2}\right)=0.167
\end{aligned}
$$

Thus the iron concentration in the solution is still much greater than the nickel concentration. The $\mathrm{Fe}^{+3}$ concentration is still insignificant. The magnetite is oxidized to goethite by oxygen carried in the water. Here, no change occurs in the magnetitetrevorite $\left(\mathrm{ss}^{\prime}\right)$ because of the stabilizing influence of $\mathrm{Ni}^{+2}$.

Reactions involved in step 4 and the attainment of the final state.-In this reaction, the magnetitetrevorite $\left(\mathrm{ss}^{\prime}\right)$ is oxidized to the maghemite-trevorite (ss) and goethite, at $p \mathrm{O}_{2}=0.20 \mathrm{~atm}$. The ion concentrations are calculated as follows:

$\mathrm{FeOOH}+3 \mathrm{H}^{+}=\mathrm{Fe}^{+3}+2 \mathrm{H}_{2} \mathrm{O}$

$\log K=0.75$

$\log K=0.75=\log \mathrm{Fe}^{+3}-3 \log \mathrm{H}^{+}$.

For a rainwater with $\mathrm{pH}=6, \log \mathrm{Fe}^{+3}=-17.25$, or $\mathrm{Fe}^{+3}=10^{-17.25}$ molal. The nickel concentration is found from

and

$$
\mathrm{NiFe}_{2} \mathrm{O}_{4}+8 \mathrm{H}^{+}=\mathrm{Ni}^{+2}+2 \mathrm{Fe}^{+3}+4 \mathrm{H}_{2} \mathrm{O}
$$

$\log K=9.59=\log \mathrm{Ni}^{+2}+2 \log \mathrm{Fe}^{+3}-8 \log \mathrm{H}^{+}$

$$
-\log \mathrm{NiFe}_{2} \mathrm{O}_{4}(\mathrm{ss})
$$

For $\mathrm{pH}=6$ (that of rainwater), $\log \mathrm{Fe}^{+3}=-17.25$, and $N\left(\mathrm{NiFe}_{2} \mathrm{O}_{4}\right)(\mathrm{ss})=0.25, \log \mathrm{Ni}^{+2}=-4.50$ and $\mathrm{Ni}^{+2}$

$$
=0.000031 \mathrm{molal}
$$

At $p \mathrm{O}_{2}=0.2$ atm there is no $\mathrm{Fe}^{-2}$ in solution, and the spinel is the observed trevorite-maghemite solid solution. The ratio $\mathrm{Ni} / \mathrm{Fe}=0.000031 / 10-17.25$ is greater than 1.0, and therefore there is no available iron in solution to enter into the silicate phase. At any other time, the dissolved iron would be sufficient in the solution to produce a mixed silicate of iron and nickel or an iron silicate.

In summary, at the final state with goethite and maghemite-trevorite (ss') at $p$ O., $=020$ atm:

$$
\begin{aligned}
& \mathrm{Fe}^{+3}=10^{-17.25} \text { molal } \\
& \mathrm{Fe}^{+2}=\text { zero! } \\
& \mathrm{Ni}^{+2}=0.000031 \text { molal } \\
& \mathrm{Ni} / \mathrm{Fe}=>>1
\end{aligned}
$$

Pecoraite, an iron-free silicate, could form only when the nickel ion is sufficiently concentrated in the solution and the activity of aqueous iron is very low. These conditions could be realized if hot water and traces of silica at approximately $80^{\circ} \mathrm{C}$ react with 
nickeloan maghemite. The silica could be obtained from the quartz which is remobilized by water to produce opal. Only in the last state of the alteration of the meteorite would the concentration of aqueous nickel exceed that of aqueous iron, and at this stage pecoraite can form.

\section{INTERPRETATION OF THE DISINTEGRATION}

The preceding analysis supplied information on the stability of iron and iron-nickel alloys in a corroding environment. The data and the theory permit evaluation of the stability, the electrochemical process of alteration, the rate of alteration, and the relative concentration of nickel and iron ions in the liquid phase at various stages in the alteration process. The metallographic observations made by Perry (1944) on altered meteorites show clearly that the kamacite in the meteorite is altered first, before the taenite. The alteration process is so selective that kamacite is completely replaced, and a pseudomorph of goethite and nickeloan maghemite that remains contains the taenite lamellae which outline the former grains and also preserve the outlines of the octahedral pattern. Only after a long and intensive alteration process do the taenite lamellae yield to the attacking solutions.

The first stage in the oxidation of the meteorite, accomplished in a succession of steps, involved the replacement of the major phase kamacite and the redistribution of the nickel between the most abundant phase goethite, the nickeloan maghemite, and the liquid phase which remained after oxidizing the alloys. The amount of nickel ion in solution at this late stage in the replacement of kamacite must have been very small, as judged by comparison with the calculations of John L. Haas for the nickel-rich alloy, taenite. Most, if not all, of the nickel may have remained in place in the pseudomorph.

Physically, the partly oxidized meteorite was cracked by the alteration, as previously described, and this was a major system of large cracks. In addition, a minor system of numerous tiny cracks must have formed in the replacement of the kamacite accompanying the increase in volume of the mass.

A network of tiny cracks was required to allow the solutions to pass through, along, or around replaced plates and grains of kamacite to reach and replace the more resistant taenite lamellae and later escape with their load of dissolved ions into the major crack system. Perry (1944, p. 24) noted, from metallographic studies, that "The hydroxide [goethite] tends to penetrate octahedrites along the planes of the Widmanstätten pattern and also along grain boundaries, and sometimes along the planes of the
Neumann lines." All these paths for the solutions to migrate into the altered mass must have been available for the late-stage replacement of taenite.

Such an assemblage of tiny cracks can be likened to a large collection of tiny misshapen hydrothermal bombs. At night, when the whole meteorite cools down to about $17^{\circ} \mathrm{C}$, the cracks are partly filled with trapped liquids and their associated vapor phase. The composition of the liquid phase may vary slightly throughout the mass. During the day, the daily heating cycle causes the temperature of the assemblage to rise, and the vapor pressure increases correspondingly. As the temperature and vapor pressure increase, a state is reached at which the cracks can no longer contain the microsystem, and they begin to leak. The leachate, with its load of dissolved constituents, leaks into the low-temperature hydrothermal environment of the major crack system. There is a certain similarity between the character of the assemblage postulated above and some accidental experimental observations.

Dr. George W. Morey (oral commun., 1960), while at the Geophysical Laboratory, Carnegie Institution of Washington, accidentally produced nickel talc in cracks in steel bombs that had leaked during hydrothermal experiments. His experiments were made at much higher temperatures and pressures than those in the natural system studied in this report. Other investigators, including Dr. Albert C. Walker, Bell Telephone Laboratories (oral commun., 1960), and Professor O. F. Tuttle, then at the Pennsylvania State University (oral commun., 1960), also observed hydrous nickel silicates formed by the leaking of heated silica-rich solutions into cracks in the nickelsteel bombs. The reactions proceeded rapidly.

Corrosion of the meteorite progressed as thermal cycles repeated. The cracks at the surface widened, and when they became wide enough, adventitious sand grains, composed chiefly of quartz, were blown into them. As the cracks expanded during the daily heating cycle, the grains dropped deeper. When the nightly cooling cycle took place, the grains contracted much more slowly than the other phases. This resistance helped widen the cracks, and the grains were themselves crushed in the process. The finer crushed grains of quartz could thus drop deeper in the cracks. Evidence of the crushed grains can be detected in association with pecoraite, and this admixture was clearly revealed in the X-ray patterns of pecoraite. Grain-size determinations based on measurements obtained from diffractometer traces give values of $542 \mathrm{~A}$ for the diameter of these crushed quartz grains in sample WC-2-1, and $371 \mathrm{~A}$ for those in sample WC-2-2. 
The sand grains were confined to the cracks in the meteorite which were wide enough to receive them. Here they were crushed until they were fine enough to be attacked by the solutions and remobilized as an opaline form of silica. The addition of silica to the system introduced another component, thus forming, in these limited regions of the meteorite, the five-component system $\mathrm{Fe}-\mathrm{Ni}-\mathrm{H}_{2} \mathrm{O}-\mathrm{O}_{2}-\mathrm{SiO}_{2}$. No diagram for this system exists. The $\mathrm{Eh}-\mathrm{pH}$ diagrams for the iron and the nickel systems, at $25^{\circ} \mathrm{C}$, show that regions of stability of the $\left(\mathrm{Fe}^{+2} \mathrm{aq}\right)$ ion lie outside the regions of probable Eh-pH relations in the meteorite, whereas the region of stability of $\left(\mathrm{Ni}^{+2} \mathrm{aq}\right)$ ions is quite large and includes the entire probable $\mathrm{Eh}-\mathrm{pH}$ region of the system in the meteorite. The concentration of nickel ions became important when the taenite lamellae were attacked by the heated solutions in the minor crack system. The calculations by Haas (p. 129) show the relative concentrations of $\mathrm{Fe}^{+3}, \mathrm{Fe}^{+2}$, and $\mathrm{Ni}^{+2}$ in the solutions. It is only in the last step in the oxidation process, when the magnetite-trevorite solid solution is being oxidized to the maghemite-trevorite solid solution, that the concentration of the nickel ions in solution grossly preponderates over the concentration of the $\mathrm{Fe}^{+3}$ and $\mathrm{Fe}^{+2}$ ions in solution. It is very likely for these reasons that pecoraite does form and an iron silicate does not form. The only silicate mineral in the meteorite is pecoraite, and it contains only very minor amounts of iron. In this connection, the general nonexistence, in sedimentary and other low-temperature environments, of minerals composed of $\mathrm{FeSiO}_{3}$, or $x \mathrm{FeSiO}_{3} \cdot y \mathrm{H}_{2} \mathrm{O}$, has long been observed by mineralogists and interpreted as evidence of the reluctance of ferrous iron and silica to react in such environments.

The greatest concentrations of pecoraite occur in the widest cracks, and so it is evident that pecoraite formed late in the paragenesis when the taenite was decomposing and the concentration of nickel ions was at its highest value in the solution. At this stage in the disintegration, the upper part of the meteorite was chiefly goethite and nickeloan maghemite with only subordinate amounts of taenite. The lower part of the meteorite probably contained some undecomposed kamacite and most of its original taenite but was chiefly composed of goethite and nickeloan maghemite. Determining the temperature relations in this heterogeneous assembly is difficult: Values for the thermal conductivity of goethite and maghemite do not exist. However, a 226.8-kg sphere of magnetite, whose thermal conductivity would probably be close to that of maghemite, would have attained, under the assumed heating rate, a temperature of $100.7^{\circ} \mathrm{C}$ at its surface. An average temperature for the meteorite and for the reacting system at this stage, when composed of the mixture of decomposed and undecomposed phases, would probably be at least $85^{\circ} \mathrm{C}-90^{\circ} \mathrm{C}$ at the center at the peak of the heating cycle. Thus the temperature in the meteorite would range from $85^{\circ} \mathrm{C}-90^{\circ} \mathrm{C}$ at the center to $100.7^{\circ} \mathrm{C}$ at the surface.

Pecoraite grew in this stress-controlled environment, and its particle size is very small. The particle size may have been controlled by the cyclical interruption of the growth process. Providing an ample supply of solution was available, growth probably took place during the daily period of 8 hours when the temperature was high. The growth process would be interrupted as the water evaporated and during the long dry periods when sufficient rainwater was not available. The jostling of the grains during the expansion and contraction cycles of the cracks would have put the grains under stress. Any or all of these conditions could have limited the growth of the pecoraite crystals.

\section{NOMENCLATURE}

The nomenclature of the hydrous nickel-magnesium silicates, the garnierite group, was critically evaluated by Faust (1966), who pointed out the vague and contradictory usages then extant. On the basis of his studies he concluded that a nickel end-member of the clinochrysotile group equivalent to nickel clinochrysotile existed and indicated that a name would be proposed for it later.

The name "nickel chrysotile" was previously proposed by Gritsaenko and Iskyul (1937) for a filling material in a crevice in leached serpentines in the nickel deposits of Kempersai, Western Kazakhstan, Russia. They stated concerning this material:

On the basis of these data it is difficult to say whether we are dealing with replacement of $\mathrm{Mg}$ by $\mathrm{Ni}$ in chrysotile asbestos or with a pseudomorph of nickel silicate after it. Because the analysis gives a ratin of oxides closer to nickel chrysotile than to garnierite we name it nickel-r.hrysotile.'

They gave a chemical analysis which shows only 0.55 percent $\mathrm{H}_{2} \mathrm{O}$, certainly a misprint for 10.55 as judged by their ratios. This corrected analysis when computed in terms of the end-members, clinochrysotile and pecoraite, gave less than 50 percent for the nickel end-member and as such did not justify a new name. The data are given in the following tabulation:

\begin{tabular}{ccc}
\hline & $\begin{array}{c}\text { Nickel chrysotile of } \\
\text { Gritsaenko and Iskyul (1937) } \\
\text { (weight percent) }\end{array}$ & $\begin{array}{c}\text { 50:50 mix ture of theoretical } \\
\text { pecoraite and clinochrysotile } \\
\text { (weight percent) }\end{array}$ \\
\hline $\mathrm{SiO}_{2}$ & 41.20 & 37.47 \\
$\mathrm{MgO}$ & 20.50 & 21.83 \\
$\mathrm{NiO}$ & 28.20 & 29.46 \\
$\mathrm{H}_{2} \mathrm{O}-\mathrm{T}$ & $\underline{11.24}$ \\
Total & $\underline{10.55}$ & $\mathbf{1 0 0 . 0 0}$ \\
\hline
\end{tabular}

${ }^{1}$ Given as 0.55 , obviously a misprint, by Gritsaenko and Iskyul (1937).

${ }^{7}$ As translated by Michael Fleischer, U.S.Geological Survey. 
Written as a structural formula, their analysis becomes

$$
\begin{gathered}
{\left[\mathrm{Mg}_{3.15} \mathrm{Ni}_{2.34}\right]\left[\mathrm{Si}_{4.25}\right] \mathrm{O}_{10}(\mathrm{OH})_{8}} \\
\underset{\text { oct }}{\mathrm{N}_{2.49}} \quad \underset{\mathrm{\Sigma}=4.25}{\text { tet }}
\end{gathered}
$$

which again emphasizes the dominance of $\mathrm{Mg}$ ions over $\mathrm{Ni}$ ions. The excess silica suggests a mixture of phases.

The physical properties reported by these authors for their nickel chrysotile, the above chemical data, and their indecision as to the purity of their sample render their name meaningless.

Shubnikova (1938), in her summary of data on new minerals, termed the substance described by Gritsaenko and Iskyul (1937) nickel-chrysotile(?), indicating by the question mark her reservation about this so-called species. She repeated their incorrect statement of their analysis.

Noll and Kircher (1952) compared their syn thetic products with a sample of "garnierite" from Noumea, New Caledonia. The electron micrographs of the natural material showed tubes just like those in the synthetic products and demonstrated that a nickelrich serpen tine-group mineral is one of the phases in the garnierite from $\mathrm{New}$ Caledonia.

This uncertainty surrounding the identity of the phase (or phases) to which the name "nickel chrysotile" had been applied clearly justified Faust, Fahey, Mason, and Dwornik (1969) in laying aside that name and proposing the name "pecoraite" for the phase which they described as the nickel analog of clinochrysotile.

A recently recorded occurrence of pecoraite in nickel-bearing rocks in South Africa has been noted by Liebenberg (1970).

\section{LITERATURE CITED}

Adams, Leason H., and Waxler, Roy M., 1960, Temperatureinduced stresses in solids of elementary shape: U.S. Natl. Bur. Standards Mon. 2, 27 p.

Baas-Becking, Laurens G. M., Kaplan, Ian R., and Moore, Derek, 1960, Limits of the natural environment in terms of $\mathrm{pH}$ and oxidation-reduction potentials: Jour. Geology, v. 68 , no. $3,243-284$.

Bates, Thomas F., [1958], Selected electron micrographs of clays and other fine-grained minerals: Pennsylvania State Univ. Mineral Industries Expt. Sta. Circ. 51, 61 p.

Bates, Thomas F., and Comer, Joseph J., 1959, Further observations on the morphology of chrysotile and halloysite, in Swineford, Ada, ed., Clays and clay minerals-Proceedings of the 6th National Conference on Clays and Clay Minerals, Berkeley, California, Aug. 19-23, 1957: New York, Pergamon Press, p. 237-248.

Birchenall, C. Ernest, 1959, Physical metallurgy: New York, McGraw-Hill Book Co., 323 p.

Bowen, Norman L., and Tuttle, Orville F., 1949, The system $\mathrm{MgO}-\mathrm{SiO}_{12}-\mathrm{H}_{2} \mathrm{O}$ : Geol. Soc. America Bull., v. 60, no. 3, p. 430-460.
Brindley, George W., 1961, Kaolin, serpentine, and kindred minerals, chap. 2, in Brown, George, ed., The X-ray identification and crystal structures of clay minerals: $2 \mathrm{~d}$ ed., London, Mineralogical Society, p. 51-131.

Budyko, Mikhail I., 1958, The heat balance of the earth's surface. Translated [from the Russian] by Nina A. Stepanova: U.S. Dept. Commerce Office Tech. Services PB 131692, 259 p.

Carroll, Dorothy, 1962, Rainwater as a chemical agent of geologic processes-a review: U.S. Geol. Survey Water-Supply Paper 1535-G, 18 p.

Casey, John N., and Wells, Allen T., 1964, The geology of northeast Canning basin, Western Australia: Australia Bur. Mineral Resources, Geology and Geophysics, Rept. 49, 61 p.

Cassidy, William A., 1954, The Wolf Creek, Western Australia, meteorite crater: Meteoritics, v. 1, p. 197-199.

Chang, Chin Wei, 1941, Experimental study of the development of adobe soil: Soil Sci., v. 52, p. 213-227.

Coker, Robert E., 1954, Streams, lakes, ponds: Chapel Hill, N.C., North Carolina Univ. Press, $327 \mathrm{p}$.

Doyle, Roger W., 1968, The origin of the ferrous ion-ferric oxide Nernst potential in environments containing dissolved ferrous iron: Am. Jour. Sci., v. 266, no. 9, p. 840-859.

Dubief, Jean, 1959, Le climat du Sahara: Algiers Univ. Inst. Recherches Sahariennes Mém., v. 1, 312 p.

Fahey, Joseph J., 1961, A method for determining the specific gravity of sand and ground rock or minerals, in Short papers in the geologic and hydrologic sciences: U.S. Geol. Survey Prof. Paper 424-C, p. 372-373.

Fankucken, Isidor, and Schneider, Milton, 1944, Low-angle scattering from chrysotiles: Am. Chem. Soc. Jour., v. 66, p. $500-501$

Faust, George T., 1948, Thermal analysis of quartz and its use in calibration in thermal analysis studies: Am. Mineralogist, v. 33, p. 337-345.

1950, Thermal analysis studies on carbonates. I. Aragonite and calcite: Am. Mineralogist, v. 35, p. 207-224.

1966, The hydrous nickel-magnesium silicates- The garnierite group: Am. Mineralogist, v. 51, p. 279-298.

Faust, George 'T., and Fahey, Joseph J., 1962, The serpentinegroup minerals: U.S. Geol. Survey Prof. Paper 384-A, 92 p.

Faust, George T., Fahey, Joseph J., Mason, Brian H., and Dwornik, Edward J., 1969, Pecoraite, $\mathrm{Ni}_{6} \mathrm{Si}_{4} \mathrm{O}_{10}(\mathrm{OH})_{8}$, nickel analog of clinochrysotile, formed on the Wolf Creek meteorite: Science, v. 165 , no. 3888 , p. 59-60.

Feitknecht, Walter, and Berger, Alfred, 1942, Über die Bildung eines Nickel- und Kobaltsilicates mit Schichtengitter: Helvetica Chim. Acta, v. 25, p. 1543-1547.

Fizeau, H. Louis, 1869, Tableau des dilatations par la chaleur de divers corps simples metalliques ou non métalliques, et de quelques composés hydrogénés du carbonne: Acad. Sci. [Paris] Comptes rendus, v. 68, p. 1125-1131.

Garrels, Robert M., and Christ, Charles L., 1965, Solution, minerals, and equilibria: New York, Harper \& Row, 450 p.

Gensamer, Maxwell, 1941, Strength of metals under combined stresses: Cleveland, Ohio, Am. Soc. for Metals, 106 p.

Glauert, Audrey M., and Lucy, J. A., 1969a, Lipid helices: Nature, v. 121 , p. 1198.

$1969 \mathrm{~b}$, Electron microscopy of lipids; effects of $\mathrm{pH}$ and fixatives on appearance of a macromolecular assembly of lipid micelles in negatively stained preparations: Jour. Microscopy, v. 89 , pt. 1 , p. 1-18.

Gritsaenko, G. S., and Iskyul, E. V., 1937, Mineralogy of the Kempersai nickel-silicate deposits: Mineral'noe Syre, no. 1, p. 20-34 (in Russian). 
Halla, Franz, and Mark, Herman, 1937, Leitfaden für die Röntgenographische Untersuchung von Kristallen: Leipzig, Verlag Johann Ambrosius Barth, 354 p.

Heymann, Dieter, Lipschutz, Michael E., Nielsen, Betty, and Anders, Edward, 1966, Canyon Diablo meteorite-Metallographic and mass spectrometric study of 56 fragments: Jour. Geophys. Research, v. 71, no. 2, p. 619-641.

Holborn, Ludwig, and Day, Arthur L., 1901, On the expansion of certain metals at high temperatures: Am. Jour. Sci., ser. 4, v. 9, p. 374-390.

Horner, Nils G., 1936, Geomorphic processes in continental basins of Central Asia: Internat. Geol. Cong., 16th, United States, 1933, Rept., v. 2, p. 721-735.

1957, Some notes and data concerning dunes and sand drift in the Gobi desert: Sci. Exped. North-Western Provinces of China under the leadership of Dr. Sven HedinThe Sino-Swedish Frned., sec. 3, Geology, pt. 5, 40 p.

Ide, John M., 1936, 'I'he elastic properties of rocks, a correlation of theory and experiment: [U.S.] Natl. Acad. Sci. Proc., v. 22, no. 8, p. 482-496.

Ingersoll, Leonard R., Zobel, Otto J., and Ingersoll, Alfred C., 1948, Heat conduction-with engineering and geological applications: New York, McGraw-Hill Book Co., 278 p.

1954, Heat conduction-with engineering, geological, and other applications: Rev. ed., Madison, Univ. Wisconsin Press, 325 p.

Jagodzinski, Heinz, 1961, Rontgen-Klein winkelstreuung an Chrysotil-Asbest: Zeitschr. Electrochemie, v. 65, no. 4, p. 313321.

Jagodzinski, Heinz, and Kunze, Günther, 1954a, Die Röllchenstruktur des Chrysotils. I. Allgemeine Beugungstheorie und Kleinwindelstreuung: Neues Jahrb. Mineralogie Monatsch., Jahrg. 1954, no. 4/5, p. 95-108.

1954b, Die Röllchenstruktur des Chrysotils. II. Weitwinkelinterferenzen: Neues Jahrb. Mineralogie Monatsch., Jahrg. 1954, no. 6, p. 113-130.

1954c, Die Röllchenstruktur des Chrysotils. III. Versetzungswachstum der Rollchen: Neues Jahrb. Mineralogie Monatsch., Jahrg. 1954, no. 7, p. 137-150.

1956, Die Röllchenstruktur des Chrysotils. IV. Berichtigung zu der Arbeit: Neues Jahrb. Mineralogie Monatsch., Jahrg. 1956, no. 3, p. 71-72.

Jakob, Max, and Hawkins, George A., 1942, Elements of heat transfer and insulation: New York, John Wiley \& Sons, Inc., $169 \mathrm{p}$.

1957, Elements of heat transfer: 3d ed., New York, John Wiley \& Sons, Inc., 317 p.

Kayser, Emanuel, 1967, Abriss der Geologie. Band I, revised by Roland Brinkmann: Stuttgart, Ferdinand Enke Verlag, $268 \mathrm{p}$.

Kheiker, Daniel M., Flantsbaum, I. M., and Bubeleva, L. V., 1967, Determination of elementary fiber dimensions in chrysotile asbestos: Soviet Physics-Cryst., v. 12, no. 3, p. 370374 (English trans.).

Kozyrin, N. A., Bezrukov, G. N., Gusel'nikov, Yu. V., and Litvin, L. T., 1968, Ob obrazovanii garniyerita (po dannym eksperimental) [On the formation of garnierite, according to experimental data]: Akad. Nauk SSSR Doklady, v. 182, no. 3, p. 678-680.

Langmuir. Donald, 1969, The Gibbs free energies of substances in the system $\mathrm{re}-\mathrm{O},-\mathrm{H}_{2} \mathrm{O}-\mathrm{CO}_{2}$ at $25^{\circ} \mathrm{C}$, in Geological Survey research 1969: U.S. Geol. Survey Prof. Paper 650-B, p. B180-B184.
Liebenberg, W. R., 1970, Mineralogy and the metallurgists: Minerals Science and Engineering, v. 2, no. 4, p. 3-23.

Longuet, Jacqueline, 1947, Synthèse de silicates de nickel, magnésium, et cobalt, présentant des structures du type kaolinite-antigorite: Acad. Sci. [Paris] Comptes rendus, v. 225, pt. 2, p. 869-872.

McCall, Gerald J. H., 1965, Possible meteorite craters-Wolf Creek, Australia, and analogs: New York Acad. Sci. Annals, v. 123, p. $970-998$.

'McKay, Robert J., and Worthington, Robert S., 1936, Corrosion resistance of metals and alloys: New York, Reinhold Pub. Corp. (Am. Chem. Soc. Mon. Ser. 71), 492 p.

Maser, Morton, Rice, Robert V., and Klug, Harold P., 1960, Chrysotile morphology: Am. Mineralogist, v. 45, nos. 5-6, p. $680-688$.

Mason, Brian H., 1962, Meteorites: New York, John Wiley \& Sons, Inc., 274 p.

1968, Australian meteorite expeditions: Natl. Geog. Soc., Research Rept., 1963 Projects, p. 189-201.

Noll, Walter, and Kircher, Heinrich, 1952, Synthese des garnierites: Naturwissenschaften, Jahrg. 39, no. 10, p. 233-234.

Noll, Walter, Kircher, Heinrich, and Sybertz, Willi, 1958, Adsorptionsvermögen und spezifische Oberfläche von Silikaten mit röhrenförmig gebauten Primarkristallen: Kolloid Zeitschr., v. 157, no. 1, p. 1-11.

1960, Über synthetischen kobaltchrysotil und seine Beziehungen $\mathrm{zu}$ anderen Solenosilikaten: Beitr. Mineralogie u. Petrographie, v. 7, p. 232-241.

O'Daniel, Herbert, and Kedesdy, Horst H., 1947, Über eine micellare Silikatstruktur: Naturwissenschaften, Jahrg. 34, no. 2, p. 55-56.

Perry, Stuart H., 1944, The metallography of meteoric iron: U.S. Natl. Mus. Bull. 184, 206 p.

Ridgway, Robert, 1912, Color standards and color nomenclature: Washington, D.C., pub. by author, 43 p., 53 colored plates.

Roberts, Herbert G., Halligan, Robert, and Playford, Philip E., 1969, Mount Ramsay, Western Australia; 1:250,000 geological series, sheet $\mathrm{SE} / 52-9$, international index, explanatory notes: Canberra, Australia Bur. Mineral Resources, Geology and Geophysics, 24 p.

Ross, Malcolm, 1968, X-ray diffraction effects by nonideal crystals of biotite, muscovite, mixed-layer clays, graphite, and periclase: Zeitschr. Kristallographie, v. 126 , no. 1-3, p. $80-$ 97.

Roy, Della M., and Roy, Rustum, 1954, An experimental study of the formation and properties of synthetic serpentines and related layer silicate minerals: Am. Mineralogist, v. 39, p. 957-975.

Scherrer, Paul H., 1918, Bestimmung der Grösse und der innern Struktur von Kolloidteilchen mittels Röntgenstrahlen: Gesell. Wiss. Göttingen, Math.-phys., Kl., Nachr., 1918, no. 1, p. $98-100$.

Schumann, Charles H., 1938, Descriptive geometry: New York, D. van Nostrand Co., 336 p.

Shubnikova, Ol'ga M., 1938, Novye mineral'nye vidy i novye nazvaniya mineralov': Akad. Nauk SSSR Inst. Geol. Nauk Trudy, vyp. 11, Mineralog.-geochem. ser. 3, p. 1-36.

Sinclair, John G., 1922, Temperatures of the soil and air in a desert: U.S. Dept. Agriculture, Weather Bur. Monthly Weather Rev., v. 50, p. 142-144.

Smith, William O., 1942, The thermal conductivity of dry soil: Soil Sci., v. 53, p. 435-459. 
Stokes, Alexander R., and Wilson, Arthur J. C., 1942, A method of calculating the integral breadths of Debye-Scherrer lines: Cambridge Philos. Soc. Proc., v. 37, p. 313-322.

1944, A method of calculating the integral breadths of Debye-Scherrer lines-Generalization to non-cubic crystals: Cambridge Philos. Soc. Proc., v. 38, p. 197-198.

Strunz, Hugo, 1938, Stereochemie der Silikatmineralien: Zeitschr. Gesamte Naturw., Jahrg. 1938, v. 5, no. 4, p. 181-189. 1966, Mineralogische tabellen [4th ed.]: Leipzig, Akad. Verlag Geest und Portig, K.G., 560 p.

Taylor, Stuart R., 1965, The Wolf Creek iron meteorite: Nature, v. 208 , p. $944-945$.

Toman, Karel, and Frueh, Alfred J., Jr., 1968a, Diffraction of X-rays by the faulted cylindrical lattice of chrysotile-lpt.] 1, Numerical computation of diffraction profiles: Acta Cryst., v. 24. sec. A., pt. 3, p. 364-373.

$1968 \mathrm{~b}$, 1)iffraction of X-rays by the faulted cylindrical lattice of chrysotile-[pt.] 2. 'T'he form, position, and width of some diffraction profiles: Acta Cryst., v. 24, sec. A., pt. 3, p. 374-379.

Turkevich, John, and Hillier, James, 1949, Electron micruscopy of colloidal systems: Anal. Chemistry, v. 21 , no. 4, p. $475-$ 485.

van Voorthuijsen, J. J. B. van Eijk, and Franzen, P., 1950, The influence of silicon dioxide on the activity of nickel catalysts: Rec. Travaux Chim., Pays-Bas, v. 69, p. 666-667. 1951, The structure and properties of compounds formed during the preparation of nickel-on-silica catalysts: Rec. Travaux Chim., Pays-Bas, v. 70, p. 739-812.

von Laue, Max, 1926, Lorentz-Faktor und Intensitatsverteilung in Debye-Scherrer Ringen: Zeitschr. Kristallographie, v. 64, p. 115-142.

Wagman, Donald D., Evans, William H., Parker, Vivian B., Halow, Iva, Bailey, Sylvia M., and Schumm, R. H., 1969, Selected values of chemical thermodynamic properties: U.S. Natl. Bur. Standards Tech. Note 270-4, 141 p.
White, John S., Jr., Henderson, Edward P., and Mason, Brian H., 1967, Secondary minerals produced by weathering of the Wolf Creek meteorite: Am. Mineralogist, v. 52, p. 11901197.

Whitmore, M. R., 1933, Aircraft finish: Indus. and Eng. Chemistry, v. 25, p. 19-23.

'Whittaker, Eric J. W., 1956, The structure of chrysotile; II, Clinochrysotile: Acta Cryst., v. 9, no. 11, p. 855-862.

1957, The structure of clinochrysotile; V, Diffuse reflexions and fibre texture: Acta Cryst., v. 10, pt. 3, p. 149-156.

Whittaker, Eric J. W.. and Zussman, Jack, 1956, The character1zation of serpentine minerals by X-ray diffraction: Minerlog. Mag., v. 31, no. 233, p. 107-126.

Williamson, Erskine D., 1919, Strains due to temperature gradients, with special reference to optical glass: Washington Acad. Sci. Jour., v. 9, no. 8, p. 209-217.

Williamson, Erskine D., and Adams, Leason H., 1919, Temperature distribution in solids during heating and cooling: Phys. Rev., v. 14, p. 99-114.

Wilson, Arthur J. C., 1949, Diffraction by a screw-dislocation: Research; a Jour. of Sci. and its Applications [London]: v. 2, p. 541-542. 1962, X-ray optics: London, Methuen and Co., 147 p.

Woodward, William E., 1948, Engineering metallurgy: London, Constable and Co., $176 \mathrm{p}$.

Yada, Keiji, 1967, Study of chrysotile asbestos by a high resolution electron microscope: Acta Cryst., v. 23, p. 704-707.

1971, Study of microstructures of chrysotile asbestos by high resolution electron microscopy: Acta. Cryst., v. 27A, v. 659-664.

Zisman, William A., 1933, Young's modulus and Poisson's ratio with reference to geophysical appucations: [U.S.] Natl. Acad. Sci. Proc., v. 19, no. 7, p. 653-665. 




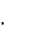

